\title{
Rethinking Iberian 'warrior' stelae: a multidisciplinary investigation of Mirasiviene and its connection to Setefilla (Lora del Río, Seville, Spain)
}

\author{
Marta Díaz-Guardamino ${ }^{1}$ (D) Leonardo García Sanjuán ${ }^{2}$ - David W. Wheatley ${ }^{3}$ - José Antonio Lozano Rodríguez ${ }^{4}$. \\ Miguel Ángel Rogerio Candelera ${ }^{5} \cdot$ Michał Krueger $^{6} \cdot$ Marta Krueger $^{6} \cdot$ Mark Hunt Ortiz $^{2} \cdot$ Mercedes Murillo-Barroso $^{7}$. \\ Veronica Balsera Nieto ${ }^{8}$
}

Received: 10 July 2018 / Accepted: 30 July 2019 / Published online: 11 September 2019

(C) The Author(s) 2019

\begin{abstract}
Iberian 'warrior' stelae have captured the imagination of researchers and the public for more than a century. Traditionally, stelae were considered 'de-contextualised' monuments, and research typically focused on the study of their iconography, paying little or no attention to their immediate contexts. As a result, despite the large number of these stelae known to date (c. 140) and the ample body of literature that has dealt with them, fundamental questions remain unanswered. This paper aims to demonstrate the potential of a multidisciplinary and contextual approach to push forward the research agenda on these monuments through a case study. Firstly, we introduce the Mirasiviene stela and the methods deployed for its investigation, which include a variety of digital imaging techniques, petrography, pXRF, intensive survey and multiscalar spatial analysis. Secondly, we discuss the results in relation to three main topics: stela biography, social practices and landscape context. Comparisons to the well-known nearby Bronze Age and Iron Age site of Setefilla are made throughout the discussion. Ultimately, this paper makes a case for the stelae of Mirasiviene and Setefilla being polyvalent monuments made by local artisans, that served both as landmarks and memorials in connection with dense late second and
\end{abstract}

Electronic supplementary material The online version of this article (https://doi.org/10.1007/s12520-019-00909-1) contains supplementary material, which is available to authorized users.

Marta Díaz-Guardamino

marta.m.diaz-guardamino@durham.ac.uk

Leonardo García Sanjuán

lgarcia@us.es

David W. Wheatley

D.W.Wheatley@soton.ac.uk

José Antonio Lozano Rodríguez

jalozano@ugr.es

Miguel Ángel Rogerio Candelera

marogerio@irnase.csic.es

Michał Krueger

krueger@amu.edu.pl

Marta Krueger

mbartk@amu.edu.pl

Mark Hunt Ortiz

mhunt@us.es

Mercedes Murillo-Barroso

murillobarroso@ugr.es
Veronica Balsera Nieto

veronica.balsera@cchs.csic.es

1 Department of Archaeology, Durham University, South Road, Durham DH1 3LE, United Kingdom

2 Department of Prehistory and Archaeology, University of Seville, María de Padilla s/n, 41004 Seville, Spain

3 Department of Archaeology, University of Southampton, Avenue Campus, Highfield Road, Southampton SO17 1BF, UK

4 Departamento de Prehistoria y Arqueología, Facultad de Filosofía y Letras, Universidad de Granada, Campus Cartuja s/n., 18071 Granada, Spain

5 Institute of Natural Resources and Agrobiology of Seville (IRNAS), CSIC, Av. Reina Mercedes, 10, 41012 Seville, Spain

6 Institute of Archaeology, Adam Mickiewicz University in Poznań, Poznań, Poland

7 Department of Prehistory and Archaeology, University of Granada, Granada, Spain

8 Archaeology and Social Processes - Institute of History, Spanish National Research Council (CSIC), Calle Albasanz 26-28, Madrid 28037, Spain 
early first millennium BCE settlement patterns in the region. Probably linked to elites, 'houses' or kin groups of this time, stelae were set in symbolically charged places, liminal spaces nearby water, burials and pathways, attracting a range of ritual activities throughout the centuries. The study of the newly discovered Mirasiviene stela shows that multidisciplinary, cutting-edge non-destructive archaeology can shed significant new light on these prehistoric monuments, thus providing a glimpse of what in our opinion is a paradigm shift in the research of similar monuments throughout Europe.

Keywords Warrior stelae · Chaîne opératoire · Petrography · Digital imaging · Fieldwalking · GIS · Landscape context · Late Bronze Age · Early Iron Age · Settlement

\section{Introduction}

In 1898, antiquarian Mario Roso de Luna published the remarkable stela of Solana de Cabañas (Cáceres, Spain), the first of a series of decorated slabs that later came to be known as 'warrior' stelae due to their rather standardised representations. Since then, Iberian warrior stelae have captured the imagination of researchers and the public for well over a century. The last 120 years have witnessed the discovery of more than 140 of these stelae and the publication of a vast scholarship on the topic that, to this date, includes six books (e.g. Almagro-Basch 1966; Barceló 1989; Galán 1993; Celestino 2001; Harrison 2004; Díaz-Guardamino 2010), as well as more than 250 papers.

Warrior stelae are characterised by an iconography, centred around panoplies of weapons and other artefacts typical of the Late Bronze Age (LBA, c. 1400/1250-850 cal BCE) (DíazGuardamino 2012). Even though numerous stelae were studied in the 1970s and 1980s, a time of methodological renovation in Iberian archaeology, publications typically focused on the formal analysis of their motifs, largely disregarding their findspots, as well as their material qualities (lithology, manufacturing techniques, etc.). Because most warrior stelae were non-stratified finds and their study was narrowly focused on their graphic motifs, they were proclaimed to be 'de-contextualised' monuments (see critique in Díaz-Guardamino 2010, pp. 31-35). But when their landscape context began to be considered in the early 1990s, research highlighted recurrent locational patterns amongst these monuments, with pathways, passage zones and valuable resources playing a major role in their location (Galán 1993; Enríquez 2006). It was not until the mid-2000s that research on warrior stelae started to make systematic contextual assessments, based on fieldwork and GIS-based spatial analysis.

\section{The 'function(s)' of warrior stelae}

One of the enduring debates on warrior stelae revolves around their functionality. In principle, this issue was addressed via their iconography, which led to an emphasis on their apparent commemorative (and perhaps funerary) dimension. More recently, this problem has been examined through highresolution landscape analysis. Whilst the mortuary significance of their iconography is broadly accepted — stelae may be held as depictions of the deceased with associated grave goods and/ or as ancestors to be remembered - many interpretations have been proposed as to their 'specific' function: including burial markers or cenotaphs (e.g. Almagro-Gorbea 1977, pp. 192 193; Celestino 2001, p. 318), territorial markers (Galán 1993), memorials linked to land claims (Enríquez 2006) or any of those roles at any given time or combined (Harrison 2004, p. 108; Díaz-Guardamino 2010, pp. 327-411; García Sanjuán 2011).

Importantly, there are references (oral accounts by the discoverers, often non-archaeologists) linking some warrior stelae to mortuary deposits (Díaz-Guardamino 2010, pp. 346-361, 368-373). Roso de Luna reported that the Solana stela was found beneath a heap of stones, lying and covering a pit that contained ashes 'as of human skeleton, the trace of a metallic instrument, spear or sword, totally destroyed by oxidation' and a pottery vessel with a handle made of yellowish clay that was handed over to him (Roso de Luna 1898, p. 180). With the years, more such cases have surfaced. In the 1970s, the Cortijo de la Reina (CR) 1 and 2 stelae (Seville, Spain) were found during the excavation of an irrigation ditch in the Guadalquivir valley (Murillo et al. 2005, pp. 25-32). CR1 was buried $80 \mathrm{~cm}$ deep lying with the decoration upside down covering three wheel-thrown biconical urns (type B2 of the region, LBA) (Murillo 1994, pp. 293-297) ${ }^{1}$ containing charred bones and ashy soil. CR2 was found $6 \mathrm{~m}$ to the north also buried at the same depth, lying with the decoration upside down. The Granja de Céspedes stela (Badajoz, Spain) was found face down, covering very deteriorated 'human skeletal remains' (Almagro Basch 1966, pp. 105-107). The relationship of the Cerro Muriano 2 and Ribera Alta/Córdoba 2 stelae, in Córdoba, Middle Guadalquivir valley, with ashes has also been reported. The first was associated with animal bones and ashes and was found about $20 \mathrm{~m}$ away from an epigraphic stela with southwestern script (Murillo et al. 2005, pp. 17-19), whilst Ribera Alta was buried $40 \mathrm{~cm}$ deep and face up, covering a layer of black earth and ashes (Murillo 1994, pp. 416-417).

\footnotetext{
${ }^{1}$ A Late Bronze Age chronology for the initial manufacture, also using the potter's wheel (probably slow wheels), and use of this type of urns was recently confirmed by the radiocarbon dating of cremated bones associated with urns A5, A47 (Aubet 1975, pp. 79, 117) and B18 (Aubet 1978, p. 196) in the necropolis of Setefilla (Brandherm and Krueger 2017, pp. 312-314).
} 


\section{Stelae with biographies}

Recent research on Iberian warrior stelae and other earlier sculptural traditions has attempted to overcome the current lack of empirical evidence on the specific activities these monuments were engaged on, both at a micro- and meso-level. Largely, effort has been concentrated on the intensive study, when possible through systematic fieldwork, of their findspots (GarcíaSanjuán et al. 2006, 2017; Díaz-Guardamino et al. 2019). Key to this work is the consideration of stelae as spatially significant monuments that endured and afforded multiple engagements, all of which are crucial to understand their social dimensions, particularly in reference to the crafting of power relations between individuals and communities across time, from their inception until much later historical periods (see also Díaz-Guardamino 2015; García-Sanjuan and Díaz-Guardamino 2015).

Usually the only evidence of reuse in these stelae comes in the form of marks of recarving, including the addition of new motifs, intentional erasure and even fracture (Díaz-Guardamino 2010, pp. 343-346). Some of the episodes of recarving have important implications for the dating of these monuments, which were traditionally considered 'closed' finds (i.e. made in one phase). Valdetorres 1, in which two human figures, a sword, a spear, a mirror and a razor blade are added to an existing shield, spear and sword, is a good example of this (Domínguez de la Concha et al. 2005, pp. 32-33; DíazGuardamino 2019). Other modifications are more difficult to date but are equally relevant to understand the changing social value of stelae through time. In some cases, however, stronger contextual evidence reinforces the suspicion that warrior stelae were connected to mortuary activities (i.e. possibly, their 'primary' use) and also in connection to their powerful and enduring symbolic value (Díaz-Guardamino 2010, pp. 355-361). Relevant to this paper is the case of the Setefilla stela (Sevilla, Spain), reused during the Early IA (EIA) to cover an inhumation grave in the context of a long-lived settlement and necropolis dating back to, at least, the middle of the second millennium BCE (see below). Two remarkable cases are those of Majadahonda and Capote (Badajoz, Spain), where Iberian warrior stelae were reused in the EIA to hold funerary inscriptions in southwestern script (García-Sanjuán and Díaz-Guardamino 2015, pp. 190-192). Another relevant case is that of the Cancho Roano stela (Badajoz, Spain), which was reused as the first stepping stone of the staircase leading to the main entrance of a gigantic building, interpreted as a sanctuary-palace. The fact that this stela was carefully placed face up on the staircase of the building, built in the fifth century BCE (Celestino 2001, pp. 20-27) not only provides a chronological clue as to the temporality of these stelae, but also reveals how significant they were ideologically. The earliest structure found at the Cancho Roano complex is an oval pit, possibly mortuary, dated to the beginning of the EIA, to which the stela is believed to have been associated (Jiménez Ávila 2009, pp. 72-73).
Towards a new multidisciplinary approach

Our recent research has combined the intensive study of stelae findspots at a micro- and meso-scale through archaeological fieldwork and landscape analysis with the high-resolution study of stelae from a biographical point of view by means of petrography and a range of digital imaging techniques (García Sanjuán et al. 2006, 2017; Díaz-Guardamino et al. $2015,2019)$. Key to this research is the investigation of the activities directly related to the stelae and their findspots, as well as the re-evaluation of settlement data in connection to them. Whilst warrior stelae have been interpreted as features linked to passage ways and valued resources in the framework of territorialisation processes taking place in western and southern Iberia during the LBA, their specific connection to individual settlements remained vague. A recent reappraisal of the data (Díaz-Guardamino 2010, pp. 373-389) reveals that stelae were frequently placed close to settlements with evidence of LBA occupation in southern and western Iberia, although they are not usually studied in connection to them (but see Pavón Soldevilla et al. 2018).

In this paper, we present a case that best encapsulates the potential of multidisciplinary research for the characterisation of stelae and their findspots in an approach that we believe can serve as a paradigm changer in the study of these monuments. This is not only because the stela of Mirasiviene and its findspot are particularly complex and rich in evidence and closely linked to Setefilla, a major Bronze Age and Iron Age site, but also because of the broad range of techniques applied to study them and the results produced, which have farreaching implications for the understanding of these monuments and the communities related to them, at local, regional and supra-regional levels.

\section{Materials and methods}

The Mirasiviene warrior stela was found in the Mirasiviene 'cortijo' (farmstead) (Lora del Río, Seville), on the contact area between the Guadalquivir River lowlands and the Sierra Morena hills (Fig. 1). Specifically, the stela was found at the foot of the Sierra's eastern most slopes, on a natural platform facing the Guadalquivir River, which lies $6 \mathrm{~km}$ to the southeast, and flanked by two streams that run towards that river. The northern half of the farm is currently pasture dotted with holm oaks, whilst the southern half is used for citrus cultivation. The houses of the farmstead are located where these two land plots meet. Two of us (LGS and MDG) first visited the farmstead in November 2011 after being tipped by Mr. Juan Francisco López Muñoz about its presence there. At that time, the stela was lying by the entrance of the state's main building, exposed to the elements. A photograph 


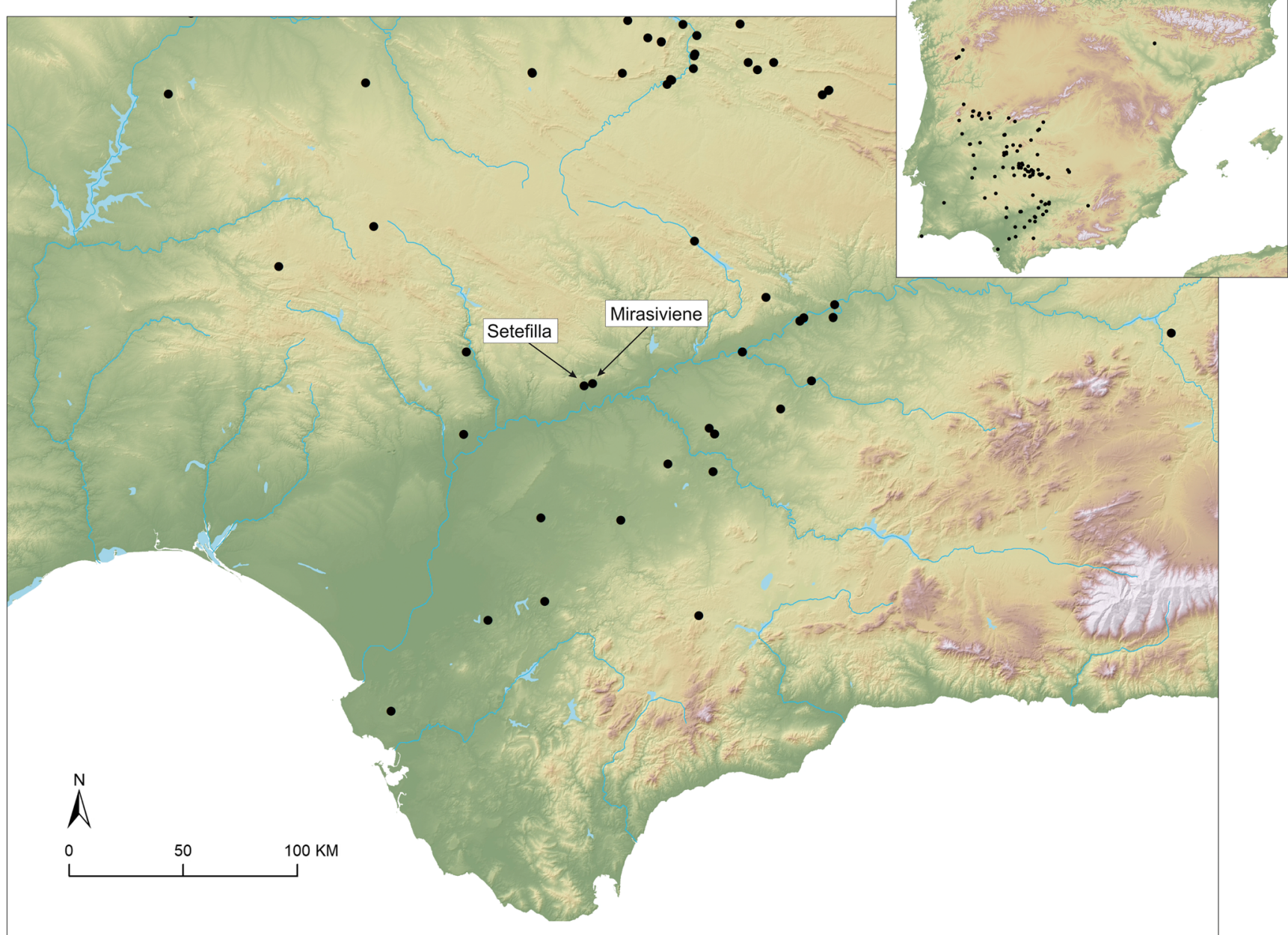

Fig. 1 Location of the stelae of Mirasiviene and Setefilla in the Guadalquivir valley and the Iberia Peninsula

taken in the 1980s (Fig. 2), however, shows the stelawith fewer lichens-lying elsewhere in the farmstead. According to the account of the landowners, Mr. Eugenio and Mr. Pedro Antonio González Sanz, the stela had been unearthed in the 1950 s, when the southern land plot was first tractor-ploughed. ${ }^{2}$

Mirasiviene lies barely $3 \mathrm{~km}$ to the East of Setefilla, a wellknown Bronze Age and Iron Age site (including settlement and necropolis) that was first excavated in the 1920s by George Bonsor and R. Thouvenot, then in the 1970-1980s by Professor María Eugenia Aubet, and for which there is an ample body of literature (Bonsor and Thouvenot 1928; Aubet 1975, 1978, 1981, 1997; Turbón 1981; Aubet and Serna 1982; Aubet et al. 1983; Torres 1996; Díaz-Guardamino et al. 2015; Brandherm and Krueger 2017; etc.). This fact alone would have made Mirasiviene very interesting by itself. In addition, on a preliminary inspection, we observed the presence of countless surface material of apparent pre- and protohistoric

\footnotetext{
2 If correct, this account would set the discovery before 1958, as that land plot appears already ploughed on orthophotos dated to that year.
}

date on the Mirasiviene findspot (as indicated by the landowners). This convinced us that a multidisciplinary project in order to study the stela, its findspot and landscape context was of the greatest interest. Thus, fieldwork was carried out in September 2012 during a 3-week season, whilst postexcavation work has been carried out throughout subsequent years.

The range of methods deployed to study the stela, its findspot and landscape context includes (1) petrographic analysis of a sample of the stela (MS-1) for determining the mineralogical composition and provenance of the stone; (2) the combined use of reflectance transformation imaging (RTI) and 3D laser scanning (explained in detail in Díaz-Guardamino and Wheatley 2013) to produce an accurate record (within the sub-millimetre range) of the surface of the slab and its engravings (Table 1$)^{3}$ and assess the chaine opératoire of its manufacture and subsequent transformations (Díaz-Guardamino et al. 2015); (3) digital image

\footnotetext{
${ }^{3}$ The RTI file of the stela, and associated metadata, can be downloaded here: https://doi.org/10.15128/r2tb09j5674. The 3D model (medium resolution) of the stela of Mirasiviene can be visualized here: https://skfb.ly/6MFSz
} 


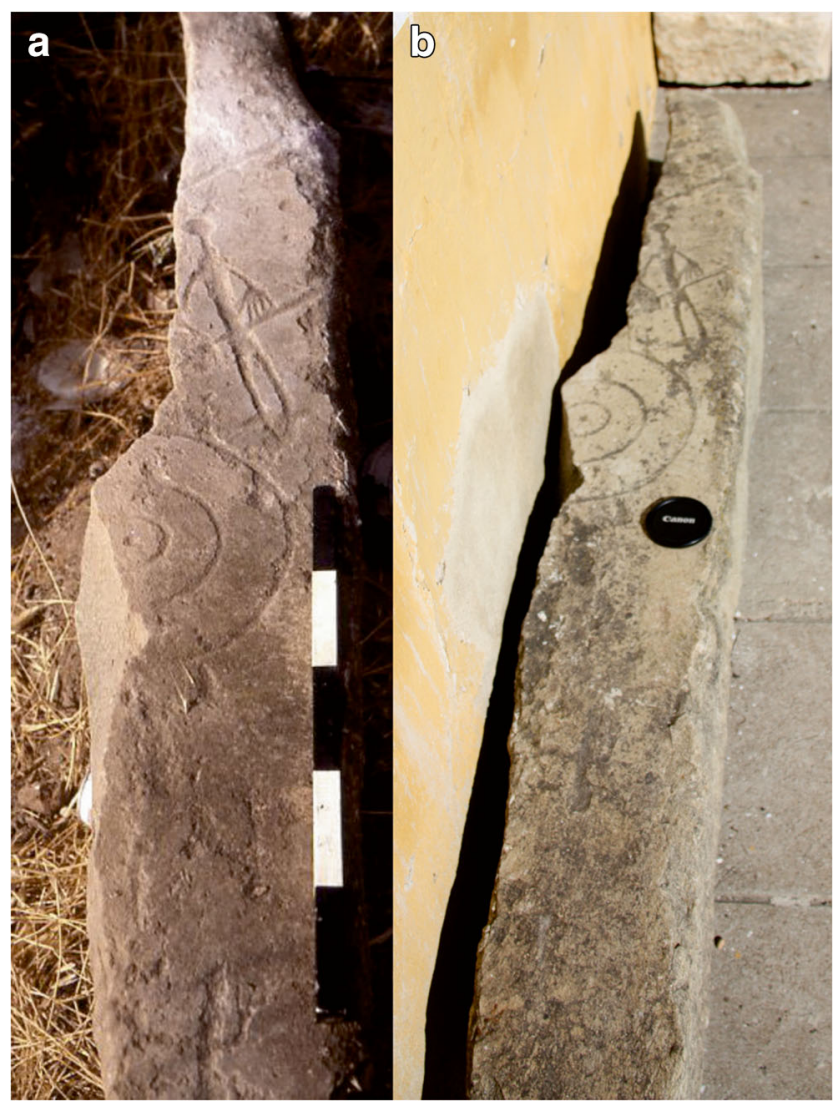

Fig. 2 a, b The stela of Mirasiviene as photographed in the 1980s and in 2011, when we first visited the farm

analysis (DIA) to detect possible traces of applied pigments (Rogerio-Candelera 2015; Supplementary Materials: Appendix A); (4) intensive surface surveying with high-resolution geo-location; and (5) X-ray fluorescence spectrometry (pXRF) and petrography for the analysis of the ceramic sherds retrieved during the survey, both explained below.

Intensive surface survey supported with a high-precision Real Time Kinematic Leica SR530 GPS followed a two-stage strategy. First, a complete coverage intensive surface survey of two transects was carried out in two different zones in the area where the stela had been found in order to assess the distribution of archaeological material (Fig. 3). These two transects measured (1) $31 \mathrm{~m}$ wide $\times 128 \mathrm{~m}$ long and (2) $29 \mathrm{~m}$ wide $\times 158 \mathrm{~m}$ long, covering a surface of 3829 and $3949 \mathrm{~m}^{2}$, respectively. They were surveyed by four non-experienced surveyors (students) accompanied by one senior member of the team; surveyors were spaced on average $2 \mathrm{~m}$. All materials recognised were recorded and photographed, whilst only those clearly diagnostic were collected

Table 1 3D models of the Mirasiviene stela: resolution data

\begin{tabular}{lll}
\hline Model & Vertices & Faces \\
\hline Medium resolution & $2,651,311$ & $5,302,598$ \\
Medium and high resolution & $6,215,556$ & $12,430,982$ \\
\hline
\end{tabular}

for further study. A second stage involved the semi-intensive fieldwalking of two areas adjacent to transect (1) towards the west and east (Fig. 3). These two areas cover a surface of 8416 and $2715 \mathrm{~m}^{2}$, respectively. Here, one team composed of two students with four experienced surveyors (responsible for GPS, photography and finds identification and recording respectively) surveyed the land following the orange tree lines, spaced $4 \mathrm{~m}$, and recorded and photographed the evidence every $10 \mathrm{~m}$ on average. All materials recognised were recorded and photographed, whilst only those regarded as significant were collected for further study. Overall, surface visibility was excellent since the area is cultivated with orange trees and cleaned of vegetation regularly. Because the bedrock is very close to the surface in some areas, especially between the lines of trees, the preservation of archaeological deposits is bad. ArcGIS Desktop 10.5 was used to process and analyse all the georeferenced information produced throughout our fieldwork.

As part of the study of the surface materials, pXRF and petrographic analysis were used to analyse a sample of 89 pottery fragments (for a detailed description of the methods used, see Supplementary Materials: Appendix B). We selected those most similar to the pottery found in LBA/EIA contexts elsewhere in the region in order to identify main technological groups, possible clay sources and added inclusions. A further aim of this analysis was to compare the ceramic productions found in Mirasiviene with those known from Setefilla, for which published work is already available (Bartkowiak and Krueger 2015).

\section{Results and discussion}

\section{The stela: chaîne opératoire of manufacture and later transformations}

Petrographic analysis, digital imaging and 3D modelling allowed us to reconstruct the chaine opératoire of the original manufacture and later transformations of the stela. We identified at least four stages of manufacture and later phases in which the surface is flaked, and the slab is broken:

1. Boulder procurement: The rock used to manufacture the stela (MS-1) (Fig. 4) is a fine-grained quartz-albite micaschist, of green schist-biotite zone facies, formed mainly by quartz, there being some albite, as well as colourless mica, green biotite and epidote. Texturally, there is certain segregation in levels somewhat richer in biotite and other levels of more thickness, formed by quartz and albite. These are metamorphic rocks derived from detrital sediments and its outcrops are found in the surroundings of the stela findspot, where there are also tabular blocks of dimensions like those of the stela produced by the natural fracturing of the outcrops exposed to erosion. This is a rock of relative high hardness if compared to other local 


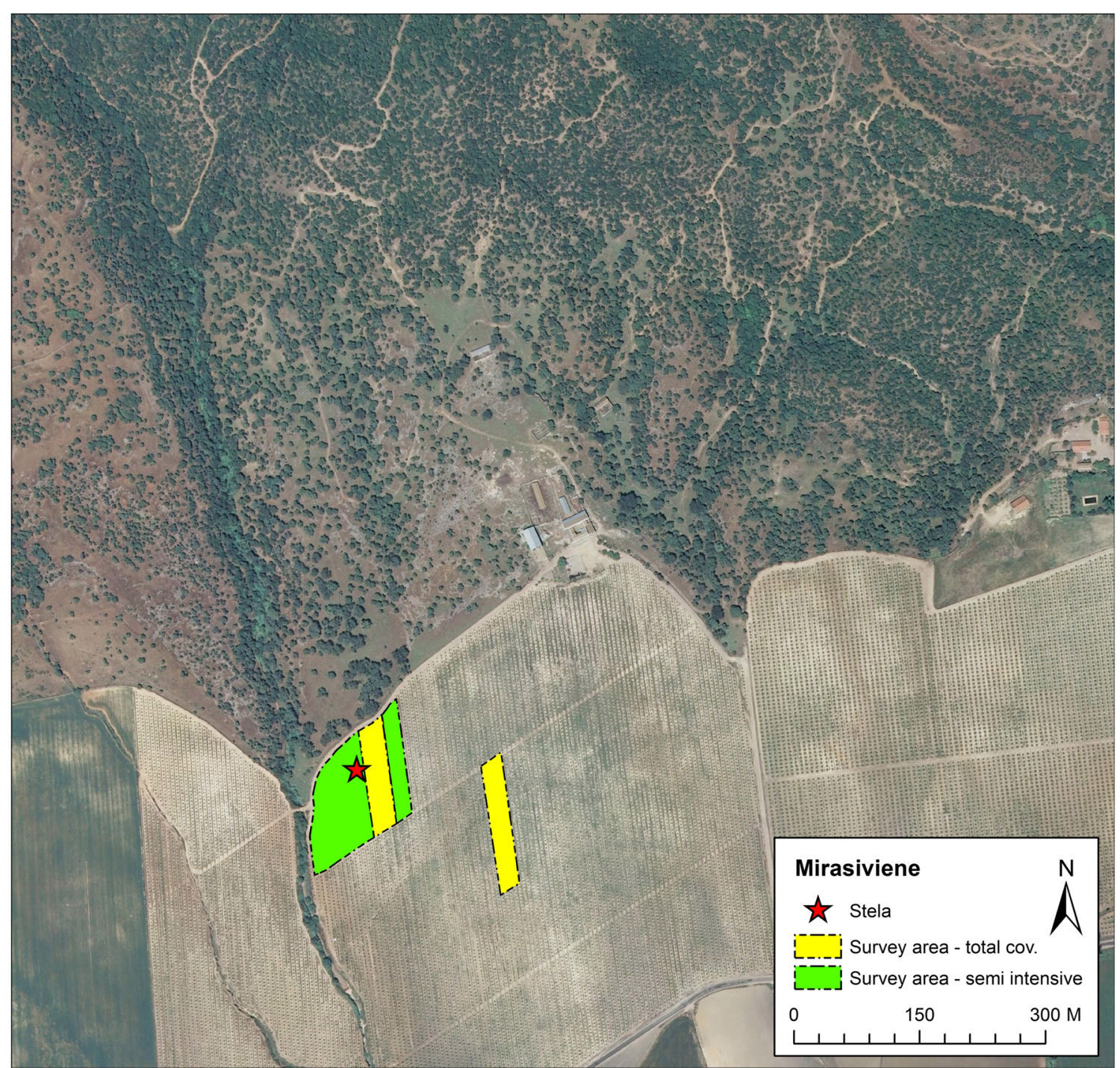

Fig. 3 Aerial view of the farmstead of Mirasiviene with indication of the stela findspot and the areas surveyed

rocks (e.g. limestone) but can be worked with stone tools made of flint, quartzite or diabase, such as the ones found at the site (see below), as a replication experiment showed (Díaz-Guardamino 2019). The surface of newly detached mica-schist blocks hardens through exposure to the elements.

The two 3D models indicate that the current volume of what is left of the stela is $0.090115576 \mathrm{~m}^{3}$, with an estimated weight of $234 \mathrm{~kg}$ (calculated with a density of $2.6 \mathrm{~g} / \mathrm{cm}^{3}$ ). If we consider that the original stela was almost double the size of the currently preserved piece (something that can be safely ascertained just by reconstructing the full outline of the shield motif), the slab could have weighed almost $500 \mathrm{~kg}$, a considerable weight to be dragged and manipulated for its shaping and erection (Fig. 5).
2. Boulder shaping: The preserved portion of the stela measures $182 \mathrm{~cm}$ in length, $23 \mathrm{~cm}$ in width and is $30 \mathrm{~cm}$ thick. Its current shape indicates that the original slab had a parallelepiped section, with flat faces (Fig. 5; https:// skfb.ly/6MFSz). The upper and lower ends are slightly rounded, but the lateral edges of the original preserved outline are angular and show multiple extraction marks (Fig. 5), indicating that considerable work was invested in shaping the original boulder.

3. Surface preparation: The surface of the obverse was levelled and smoothed entirely. Groups of parallel grooves crossing the surface in different directions, produced by abrading a rocky tool to smooth the surface, can be identified by means of RTI in the lower section of the obverse, less so in the mid and upper sections (Figs. 6a and 7; https://doi.org/10.15128/r2tb09j5674). 
Fig. 4 Micro-photographs of thin sections of the sample MS-1.

Captures a and $\mathbf{c}$ were taken with crossed nicols, whilst $\mathbf{b}$ and $\mathbf{d}$ show the same area of the thin section without crossed nicols. Zoom $\times 10$. Qtz, quartz; Mt, ore; $\mathrm{Bi}$, bivalve; Mc, colourless mica; $\mathrm{Zr}$, zircon
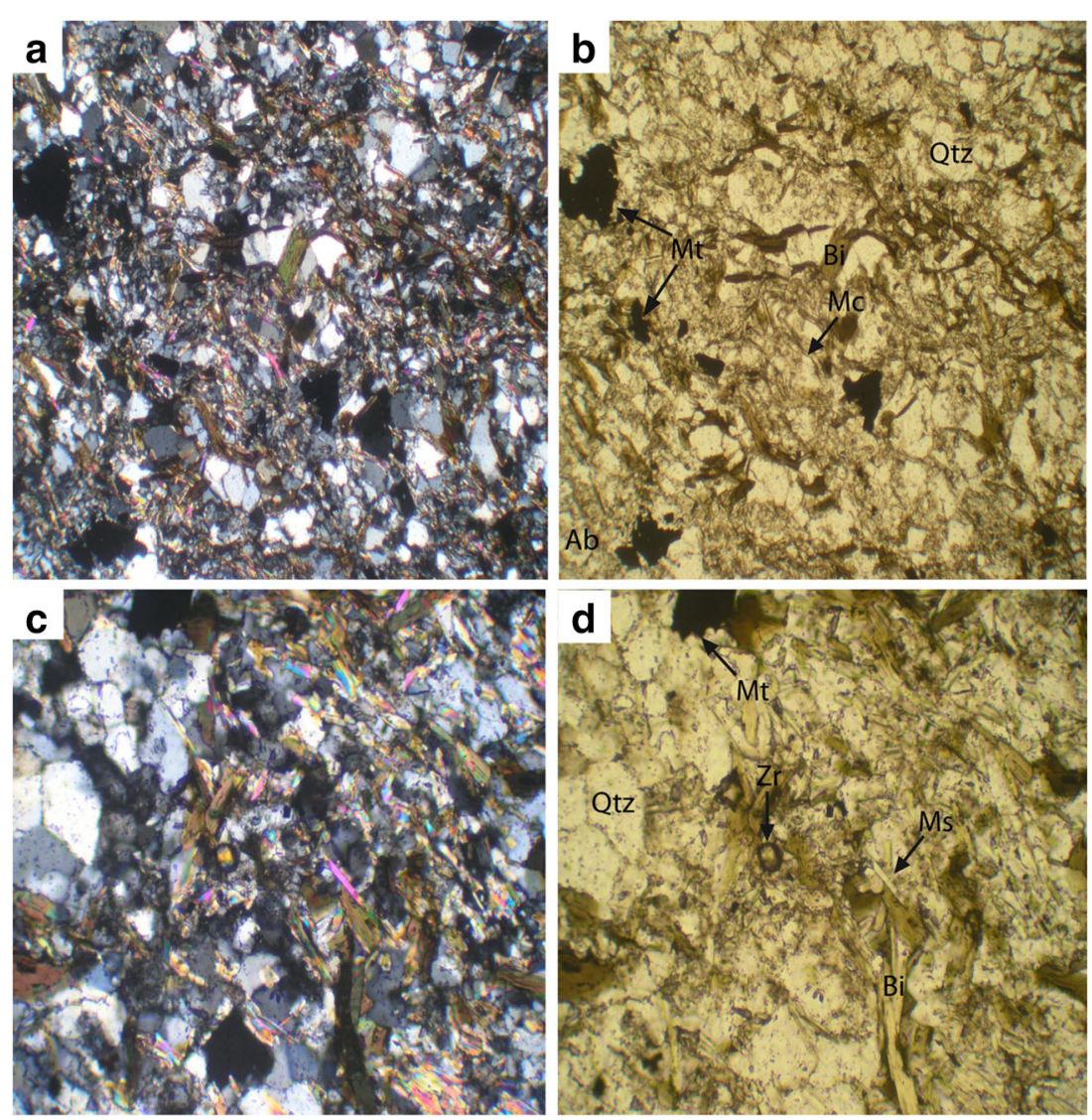

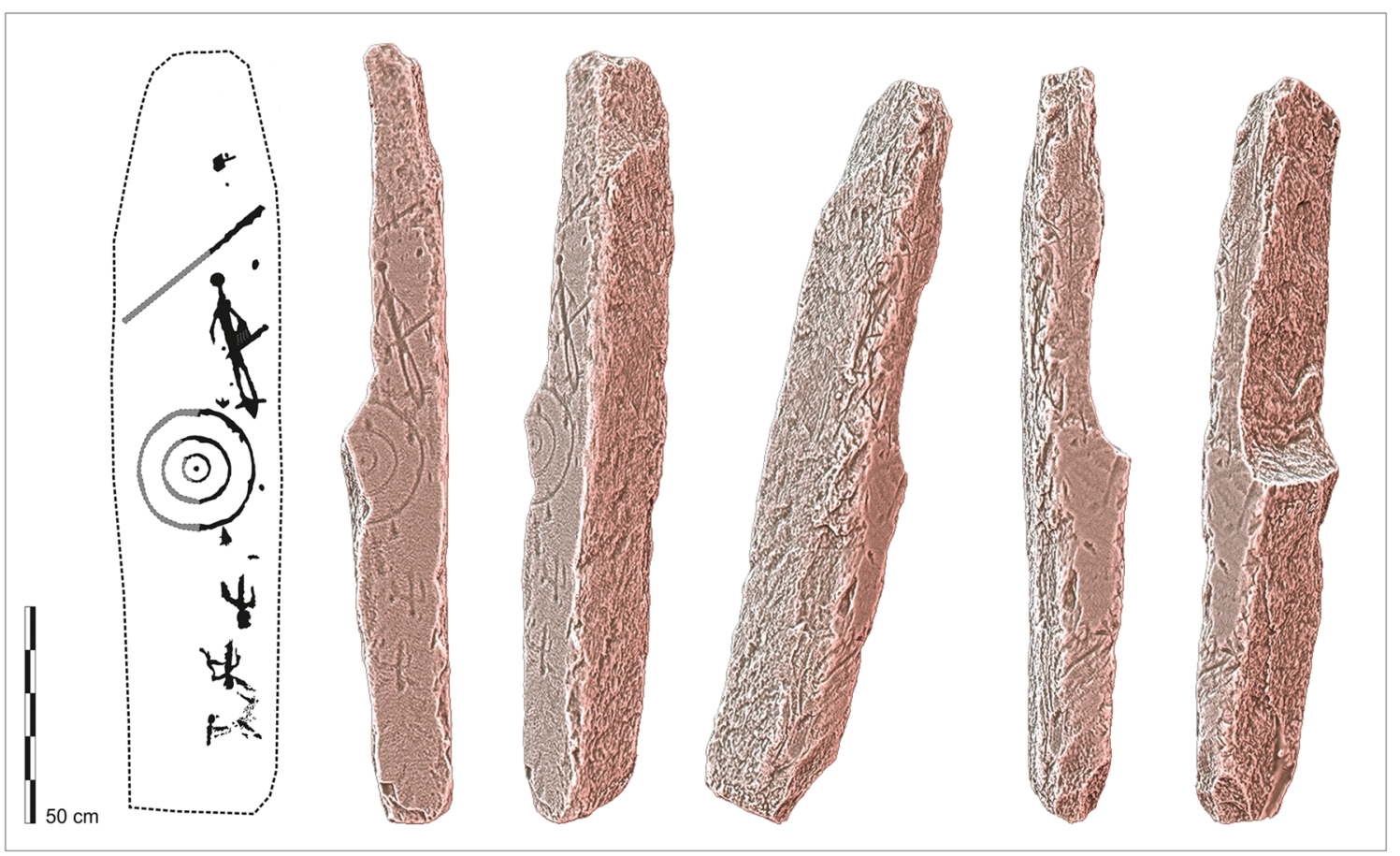

Fig. 5 Hypothetical reconstruction of the full outline of the obverse of the stela (left) and various views of the 3D model of the surface of the stela (also available here: https://skfb.ly/6MFSz) from different angles with radiance scaling rendering enhancement (produced via Meshlab, Cignoni et al. 2008; Vergne et al. 2010) showing marks left through the shaping of the boulder (especially on the edges) and the recent fractures 


\section{MIRASIVIENE (Lora del Río, Sevilla)

Levelled surface
Pecking and abrading
Pecking
Slight pecking
Incision
Flaking
Grooves (Surface levelling?)

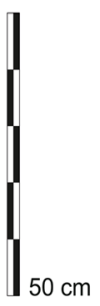

Fig. 6 Interpretative synthesis of the marks identified on the obverse of the Mirasiviene stela, with indication of the different carving techniques used, superimposition between marks, when identified, sequence of

The DIA did not detect evidence of pigments on the obverse of the stela. The study of the correlation matrix of the images obtained allowed discovering the high correlation between the bands, with values especially high for the pairs red/ green and green/blue. The lowest correlation is verified for the bands red/blue, with an average of $0.935 \pm 0.018 N=8$ (Table 2), fully justifying the utilisation of PCA for reliably enhancing the presence of hypothetical pigments applied on the surface of the stela. Consequently, with the data extracted from the correlation matrices already explained, the different band products of PCA show a great percentage of the variance of the images enclosed in the first principal component, remaining in the third the residual information, lower than $0.2 \%$ of the total variance (Table 3 ).

From a purely photo-interpretive point of view, the bands corresponding to the third principal component showed the presence of black points over a greyish general background, with some whiter areas (Fig. 8), not assignable to any recognisable pattern identifiable as a pictorial decorative motif. Figure 8 is significant with respect to the rest of the obtained images. The only visible coverages in the third principal component band are those black stains and whitish areas already mentioned (Fig. $8 \mathrm{~b})$. These last ones coincide with areas with a diffuse reddish pigmentation, corresponding with natural

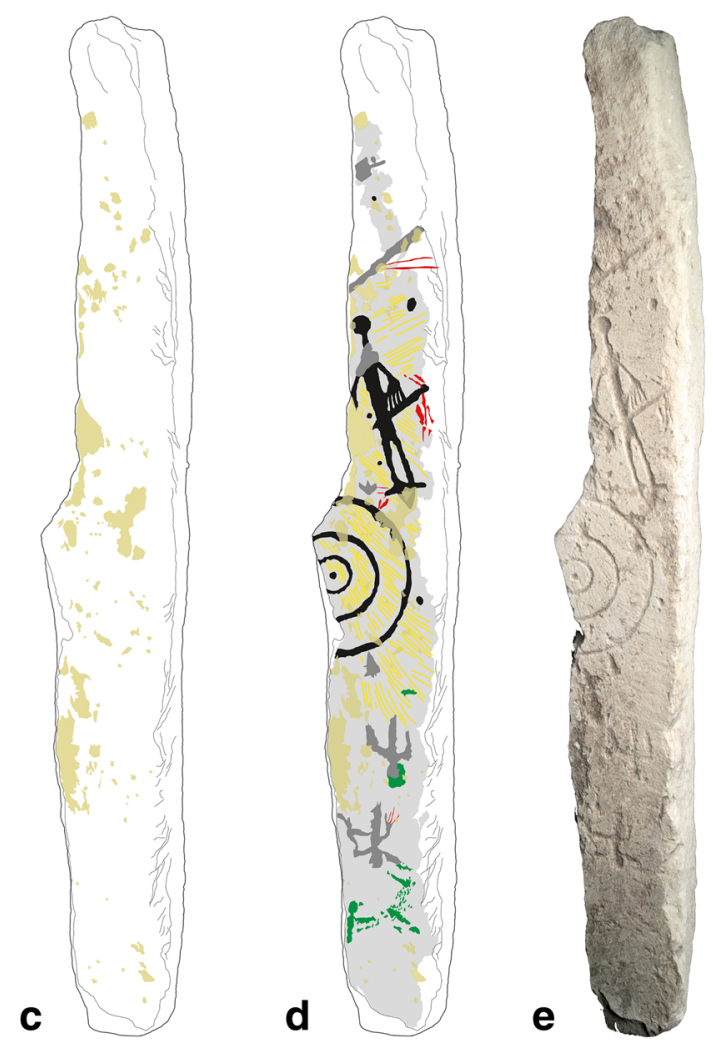

manufacture $(\mathbf{a}-\mathbf{c})$ and present state $(\mathbf{d})$. e a RTI snapshot of the stela with diffuse gain enhancement

concentrations of iron oxides on the surface of the supporting rock. The dendritic aspect of the black stains and the fact that they appear inside the engraved areas (i.e. the areas maintaining higher relative humidity for a prolonged time) suggest they are biologically originated coverages, very probably lichens. The rock is also profusely colonised by cyanobacteria, darkening the natural tone of the supporting rock (Fig. 8a). In general terms, false colour images obtained using the three PCA bands (Fig. 8c) seem to describe the general aspect of the rock in reddish tones, cyanobacterial epilithic biofilms in bluish tones, other biological coverages in greenish tones and the stains of iron oxides (hydroxides) in whitish tones. Definitely, none of the studied images allowed us obtaining data leading to consider that the Mirasiviene stela ever received a surface treatment implying the intentional application of pigments.

4. Engraving of motifs (one or more sessions) (Fig. 6b): There is a range of motifs carved with different techniques and which, presumably, may have been carved at different times, although there are no clear superimpositions and only two motifs show possible traces of recarving: the main human figure and a secondary human figure. 


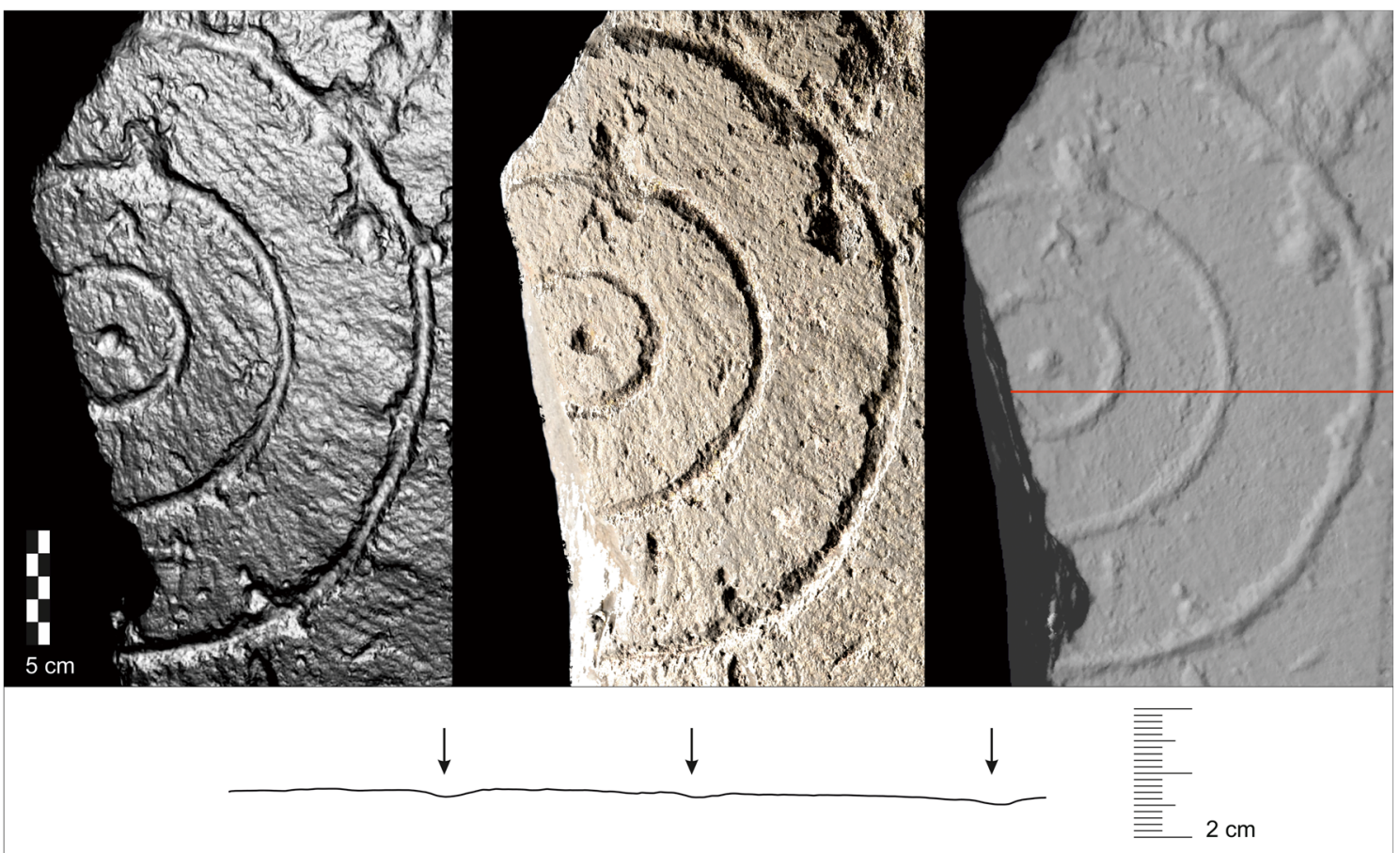

Fig. 7 RTI snapshots of the surface of the obverse in the area of the shield (left: specular enhancement filter; centre: diffuse gain filter) and capture of the high-resolution 3D model (right) with indication of the section

4.1 Motifs engraved with pecking and abrasion: The central shield and human figure were made with great skill. The shield is made of three concentric grooves (avg. $9 \mathrm{~mm}$ wide, 1.5-2 mm deep) and a central cup-mark and was partially eliminated when the stela was fragmented (Fig. 7). The human figure (Fig. 9), which is also affected by the breakage of the slab, shows a large cup-mark depicting the head ( $27 \mathrm{~mm}$ wide) and a sword on its waist; due to the careful abrasion of the grooves, it is difficult to establish the carving sequence. The torso and the sword seem to have been made in tandem: the groove of the former (c. $4 \mathrm{~mm}$ ) is deeper than that of the sword (c. $2 \mathrm{~mm}$ ), which is cut by it. The grooves outlining the legs (Fig. 9) continue and converge; they are made with the same technique as the rest of the figure, although these grooves, jointly with the torso of the human body, outline a figure of what could have been the initial design of a motif that was later discarded. There are various cup-marks scattered across the surface, two on the left side of the body. shown below. The RTI datasets can be downloaded here https://doi.org/ 10.15128/r2tb09j5674.

4.2 Motifs made with pecking (no abrasion): Two features were carved over the human figure after it was completed: dense pecking in the areas of the shoulders and neck and beneath the feet (Fig. 9). Above the human figure, there is a linear feature (spear mast?) and a quadrangular element with handle (Figs. 6b and 10). There is also a motif in the shape of an arrowhead next to the human figure's right foot. In the lower section, there are two figures, possibly a human figure and a quadruped, both in inverted position (Fig. 10). There are no superimpositions here, and therefore, it is not possible to establish whether these two motifs were carved before or after the shield and the human figure. Still, the fact that their grooves are broader and shallower (c. $1.5 \mathrm{~mm}$ ) than those and not abraded suggests they were made by a different carver, probably at a different time.

4.3 Shallow pecking: Detected in the lower end of the obverse, these seem to be unfinished motifs associated to the inverted anthropomorphic and quadruped figures (Figs. 6b and 10).

Table 2 Correlation of the different bands of a set of images

\begin{tabular}{|c|c|c|c|c|c|}
\hline \multicolumn{2}{|l|}{ Red-blue } & \multicolumn{2}{|c|}{ Red-green } & \multicolumn{2}{|c|}{ Green-blue } \\
\hline $\bar{x} *$ & 0.93481112 & $\bar{x} *$ & 0.97601569 & $\bar{x} *$ & 0.98436587 \\
\hline$\sigma^{*}$ & 0.018435176 & $\sigma^{*}$ & 0.00591868 & $\sigma^{*}$ & 0.00462954 \\
\hline $2 \sigma$ & 0.036870352 & $2 \sigma$ & 0.01183736 & $2 \sigma$ & 0.00925908 \\
\hline
\end{tabular}

$* N=8$ 
Table 3 Percentage of the total variance resumed by the bands obtained by principal components analysis of the three images studied in this work

\begin{tabular}{llll}
\hline Id. image & Band & Eigenvalue & Explained variance (\%) \\
\hline 1451 & 1 & 5889.037 & 97.6425499 \\
& 2 & 132.624 & 2.19895809 \\
& 3 & 9.559 & 0.15849198 \\
1455 & 1 & 5077.457 & 97.5332101 \\
& 2 & 119.347 & 2.29254448 \\
& 3 & 9.071 & 0.17424544 \\
1457 & 1 & 8104.425 & 97.8248865 \\
& 2 & 173.099 & 2.08940055 \\
& 3 & 7.101 & 0.08571299 \\
\hline
\end{tabular}

4.4 Incised lines: These are three sets of two or more incised parallel lines, of varying thickness, whose intentionality seems plausible as they relate to existing carved motifs (Figs. 6b, 9 and 10).

5. Surface flacking (Fig. 6c): This is distributed across the whole surface of the obverse, possibly produced by a variety of processes, some perhaps intentional, other unintentional, including weathering.

6. Slab breakage: At present, the slab is only a fraction (possibly half) of the original stela and presents two consecutive longitudinal fractures on the left side affecting the carvings (https://skfb.ly/6MFSz). The upper fracture is clearly recent, probably due to mechanical action (impact of the plough when the stela was found?), whilst the surface of the lower fracture shows more patina, suggesting an older date.

According to current classifications, the iconography of this stela corresponds to the type IIC or A (Pingel 1974; Díaz-Guardamino 2010), which includes one or more human figures. The chronology of these stelae is problematic, although the available evidence (i.e. radiocarbon dates associated with the artefacts depicted) suggests an extended period of manufacture, between c. 1200 and 800/750 cal BCE (Díaz-Guardamino 2012). The iconography of the Mirasiviene stela presents affinities with the Setefilla one (Aubet 1997), found barely $3 \mathrm{~km}$ away. However, the sequence of manufacture and the sets of techniques used to create the Setefilla stela (Díaz-Guardamino et al. 2015), as well as other stelae recently studied by us (Fig. 11), differ markedly from those recorded at Mirasiviene, underlining the 'glocal' (i.e. simultaneously local and global, the latter in reference to situated known worlds) character of these monuments. Warrior stelae were made on the basis of idiosyncratic approaches, most probably by locals who had knowledge of broadly shared symbols

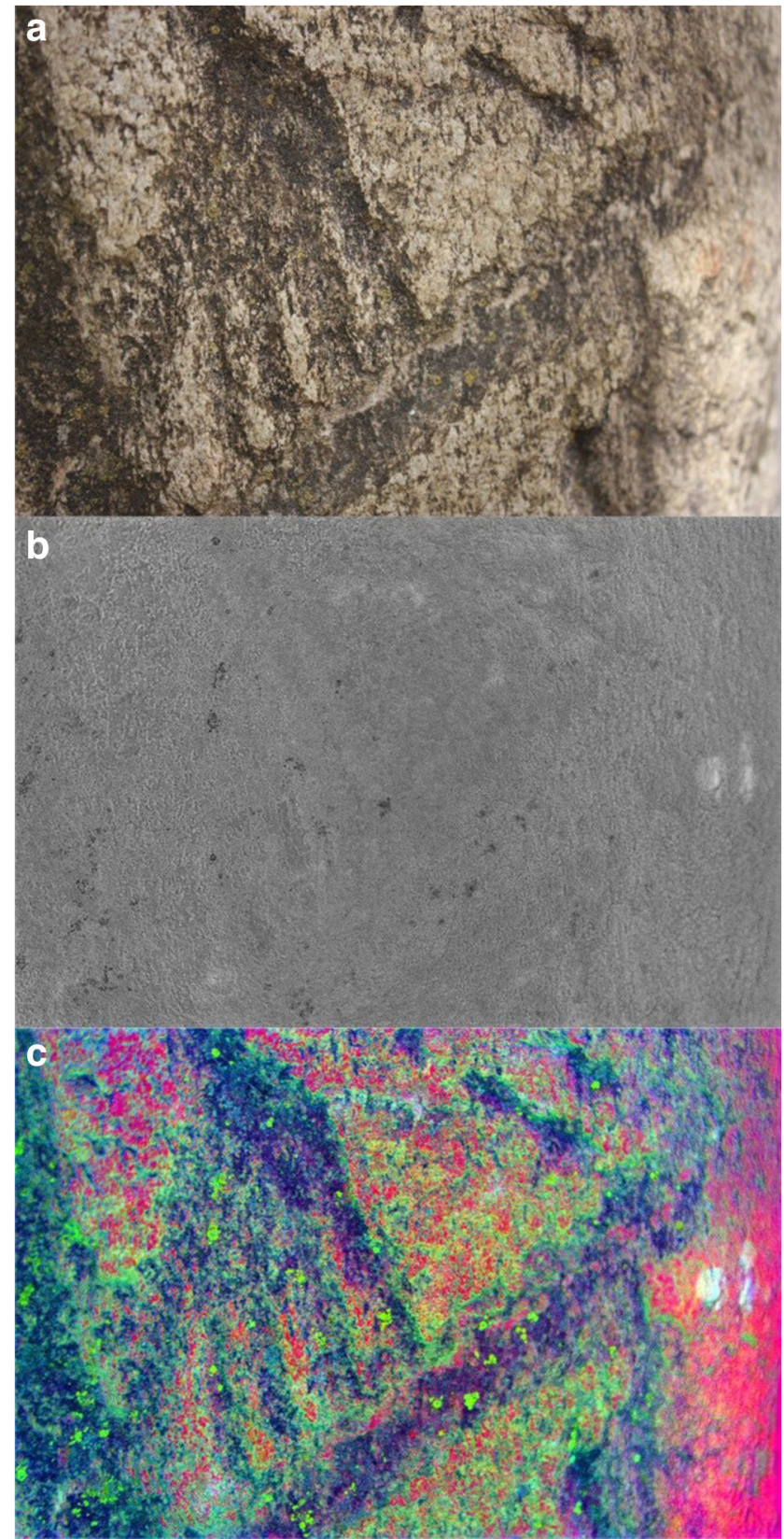

Fig. 8 Photograph 1479: a conventional RGB image, $\mathbf{b}$ third PC band and $\mathbf{c}$ false colour image elaborated with the three PCA bands

and iconographic conventions (Díaz-Guardamino et al. 2019). Testament to this are the formal traits that the Mirasiviene stela shares with other stelae from the Middle Guadalquivir River valley, such as Montemayor (found $83 \mathrm{~km}$ to the southwest of Mirasiviene), and particularly with some from the Zújar valley, in the Middle Guadiana basin, such as Cabeza de Buey 3, located 136 $\mathrm{km}$ to the northeast of Mirasiviene (Fig. 12; DíazGuardamino 2010). The chaîne opératoire of manufacture of these stelae has not been investigated yet, so it is not possible to compare them with that of Mirasiviene or Setefilla. 

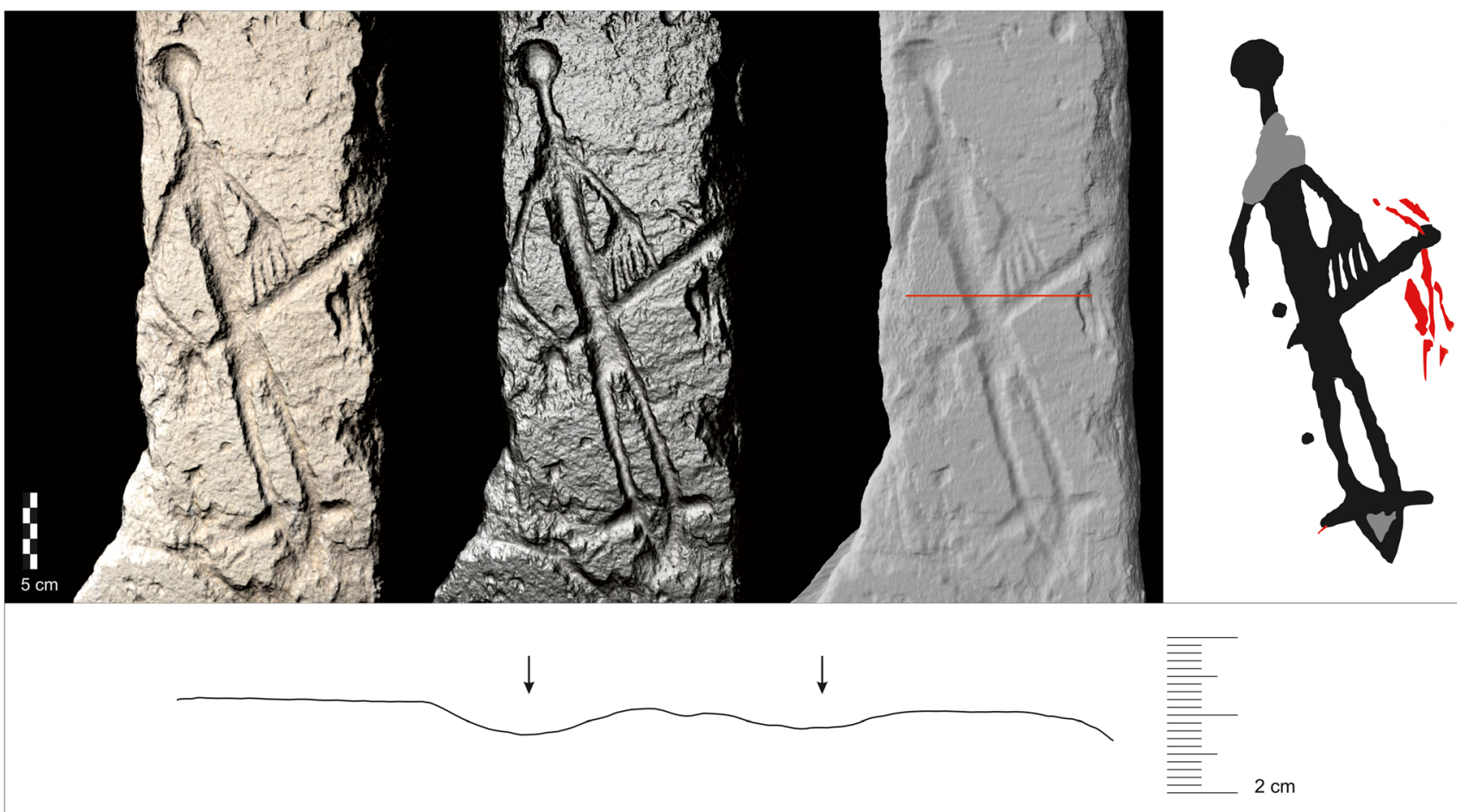

Fig. 9 RTI snapshots of the surface of the obverse in the area of the human figure (left: diffuse gain filter; centre: specular enhancement filter) and capture of the high-resolution 3D model (right) with indication

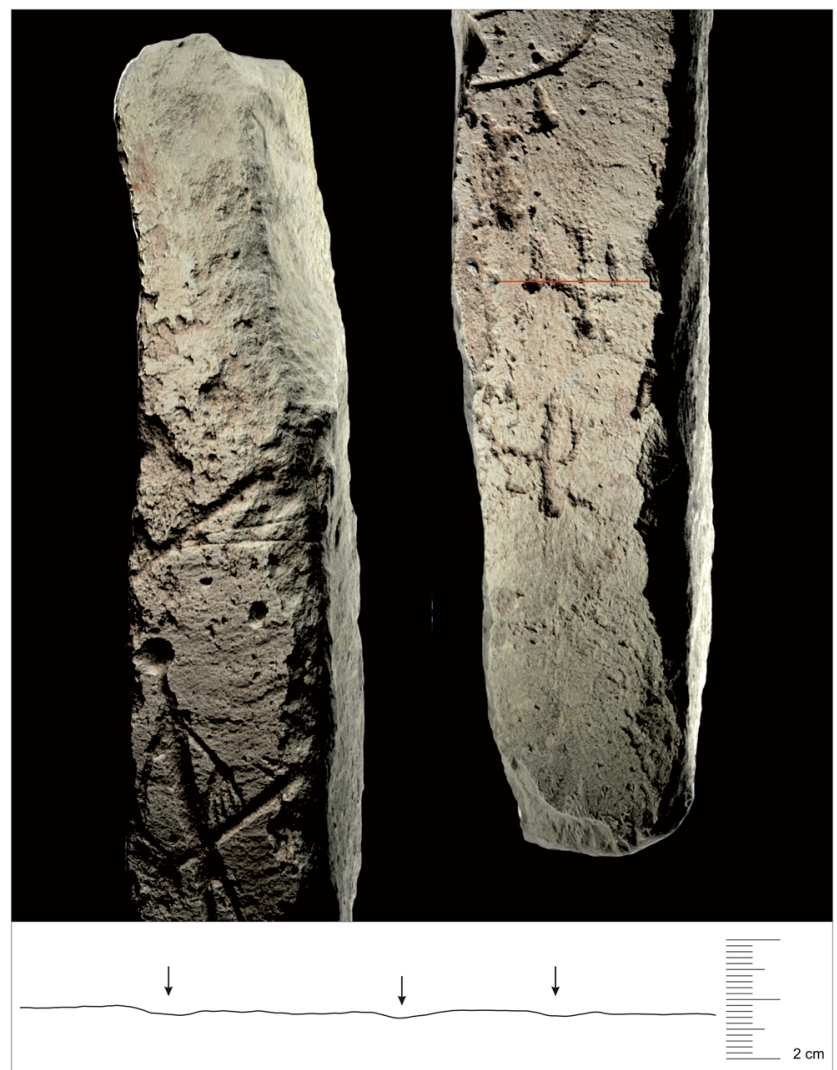

Fig. 10 RTI snapshots of the upper and lower areas of the obverse of the stela (diffuse gain filter) and (right) indication of the section shown below of the section shown below. The RTI datasets can be downloaded here: https://doi.org/10.15128/r2tb09j5674

\section{Stela findspot: artefacts and social practices}

\section{Archaeological material: categories and spatial distribution}

The Mirasiviene stela was found on a gentle slope slightly inclined to the $\mathrm{W}-\mathrm{SW}$, where there is a small valley run by a stream where naturally smoothed boulders of mica-schist can be found. Fieldwalking revealed a very high density of archaeological material in the area, especially pottery (Table 4 , Fig. 13). In total, more than 6000 pottery sherds were recorded (Fig. 14, Table 7).

The lithic assemblage recorded showed some interesting traits. Apart from flint nodules and chipped flint, a material that is not native from this area, we documented three polished stones and three hammer-like tools (Table 5; Figs. 15 and 16), all of which could be associated with prehistoric activity (perhaps the manufacture of the stela itself). Added to that, we documented nine grinding stones (some of them had flat smoothed surfaces) of uncertain chronology.

Some of the material recorded was non-prehistoric, like one fragment of glass or a copper alloy fitting, possibly part of a broken pendant, exhibiting some silver decoration (remains of silver amalgam have been detected on its surface, see Appendix D). The slagged material documented at the site (Fig. 17) seems to be related to accidental exposure of clay to high temperatures, although one of the samples analysed by 

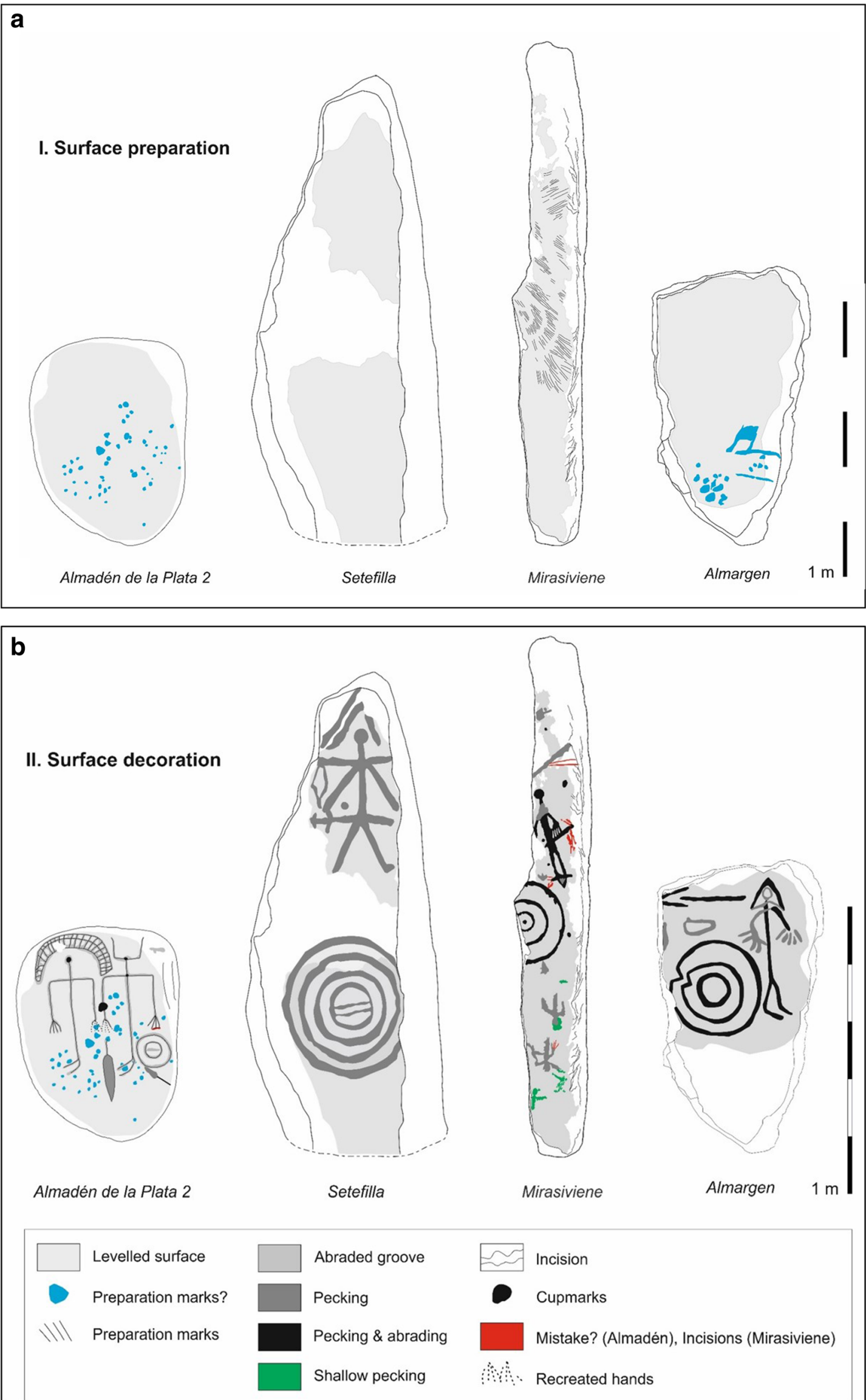
Fig. 11 a, b Interpretative synthesis of the carving techniques and sequence of manufacture of the marks identified on the obverses of the stelae of Almadén de la Plata 2, Setefilla, Mirasiviene and Almargen

XRF (Table 6; sample 1/10/2012) can be considered an iron, perhaps smithing slag, in which the occasional presence of low copper content is not unusual. Some faunal remains were also found (Fig. 17; Table 4). Four of these bone fragments were charred, ${ }^{4}$ as well as 87 pottery fragments. Whilst this is a small quantity if we consider the large amount of pottery found at the site, it is something to consider when interpreting the activity at the site.

\section{Ceramic assemblage: clay sources, manufacture, vessel form and decoration}

Pottery manufacturing technique could only be determined for $33 \%$ of the recorded sherds: 1873 were hand-made and a smaller amount (254) wheel-thrown made (Table 7). In terms of vessel form, most fragments were non-diagnostic (6118), whereas others include carinated walls (20), rims (175), bases (46) and handles (23). Some fragments showed surface treatment: 80 were burnished (some with decoration in lattice pattern), 3 incised (one with lattice pattern) and 9 painted (Table 7). Whilst many of the fragments had a pre- or protohistoric look (Fig. 18), others seemed to be more modern, including some that were seemingly Roman, Medieval or Early Modern, indicating long-term persistent activity at the site (Fig. 14).

A sample of 89 sherds of apparent pre- and protohistoric date, including 77 fragments collected at the stela findspot and 12 sherds found at the nearby settlement (see below), was analysed to determine clay composition, manufacturing technique, vessel shape/type and decoration (see Appendices B and $\mathrm{C}$ ). The results of the chemical composition analysis by means of pXRF identified two groups of samples that are comparable, in terms of quantities of potassium and titanium, to pottery from the nearby Setefilla funerary tumuli A and B (38 samples), whose fabric has been classified in two main categories: local or 'foreign' (Bartkowiak and Krueger 2015; Krueger and Brandherm 2019). In Mirasiviene, one group (22 sherds, $25 \%$ of the sampled material) is characterised by the high concentrations of potassium and is comparable to the results for 'foreign' pottery from Setefilla (Fig. 19: A), whilst another group ( 7 sherds, $8 \%$ of the sample) with high concentrations of titanium and low concentrations of potassium is perfectly coherent with the results for the local pottery from Setefilla (Fig. 19: B).

Petrographic analysis allowed the grouping of the Mirasiviene samples into various classes (I-III, type of clay

\footnotetext{
$\overline{{ }^{4}}$ Although its nature (animal or human) could not be ascertained, one of these fragments was radiocarbon dated, providing a date of $1204 \pm 28$ BP (CNA3376 ), or $715-893 \mathrm{cal} \mathrm{AD}$, which obviously makes it unrelated to the LBA use of the site.
}

used and naturally present inclusions) and groups (A-G, nonplastic elements in the clay matrix and some technological attributes) (Table 8, Fig. 20). The results offer interesting insights when compared to those from the Setefilla graves (Bartkowiak and Krueger 2015), revealing similarities in the pottery fabric of both sites. A ferruginous group (I/A-C from Mirasiviene, 46 sherds, $52 \%$ of the sample) resembles class I from Setefilla ( 8 sherds, $21 \%$ of the sample); however, the types of clay are not the same but rather similar, probably acquired from small distance from these settlements. The closest similarity was observed between group III from Setefilla (3 sherds, $8 \%$ of the sample) and group B from Mirasiviene (27 sherds, $30 \%$ of the sample) with identical intrusive igneous rock fragments such as gabbro, diabase or basalt. The relations between calcareous clay from Mirasiviene (group D, 6 sherds, $7 \%$ of the sample) and Setefilla (group VB, 7 fragments, $18 \%$ of the sample) were also observed, and it suggests a similar source of light clay. However, the pottery from both sites is significantly different and there is no evidence for their identical origin. Especially interesting is group VIII from Setefilla, which corresponds well with group E from Mirasiviene. This sandy clay with numerous grains of quartz and feldspar seems to be common for Mirasiviene ( 8 sherds, $9 \%$ of the sample), and it is represented only by one fragment from Setefilla (from a total of 38 samples).

Most of the rims collected at Mirasiviene correspond to vessels that fall within the broad categories of bowls ('cazuelas') (e.g. Fig. 18), plates and urns, many of them reproducing forms recorded in the LBA/EIA grave goods of Setefilla tumuli A and B (Aubet 1975, 1978). Some of the bowls with clearer links include, for example, Fig. 18: 57. Some of the plates found at Mirasiviene show burnished surfaces, mostly inside (Fig. 18: 69-71) but also outside (Fig. 18: 77), and there is one example showing an inside latticepatterned burnished decoration ('retícula brunida'), also found in Setefilla (Fig. 18: 48). Finally, there are rims that seem to correspond to biconical urns (e.g. Fig. 18: 56, 64), and one to a hand-made painted à chardon urn (Fig. 18: 24).

Whilst these forms and decorations are found across domestic contexts in the Lower and Middle Guadalquivir valley during the LBA and the transition to the EIA (Ruiz Mata 1995; Murillo 1994; Aubet et al. 1983), Setefilla's mounds $\mathrm{A}$ and $\mathrm{B}$ offer the best point of comparison to assess the assemblage recorded at Mirasiviene. This is not only because both sites are located very close to each other (less than $3 \mathrm{~km}$ away, see below), but also because their pottery shares certain technological traits, and both are warrior stela loci sharing similar landscape settings (see below).

\section{Social practices}

The reassessment of the chronology of Setefilla's mounds A and B by means of radiocarbon dating of cremated human remains 
Fig. 12 Warrior stelae of Montemayor (Córdoba) and Cabeza de Buey 3 (Badajoz). Line drawing: Marta DíazGuardamino; photograph: Vicente Novillo

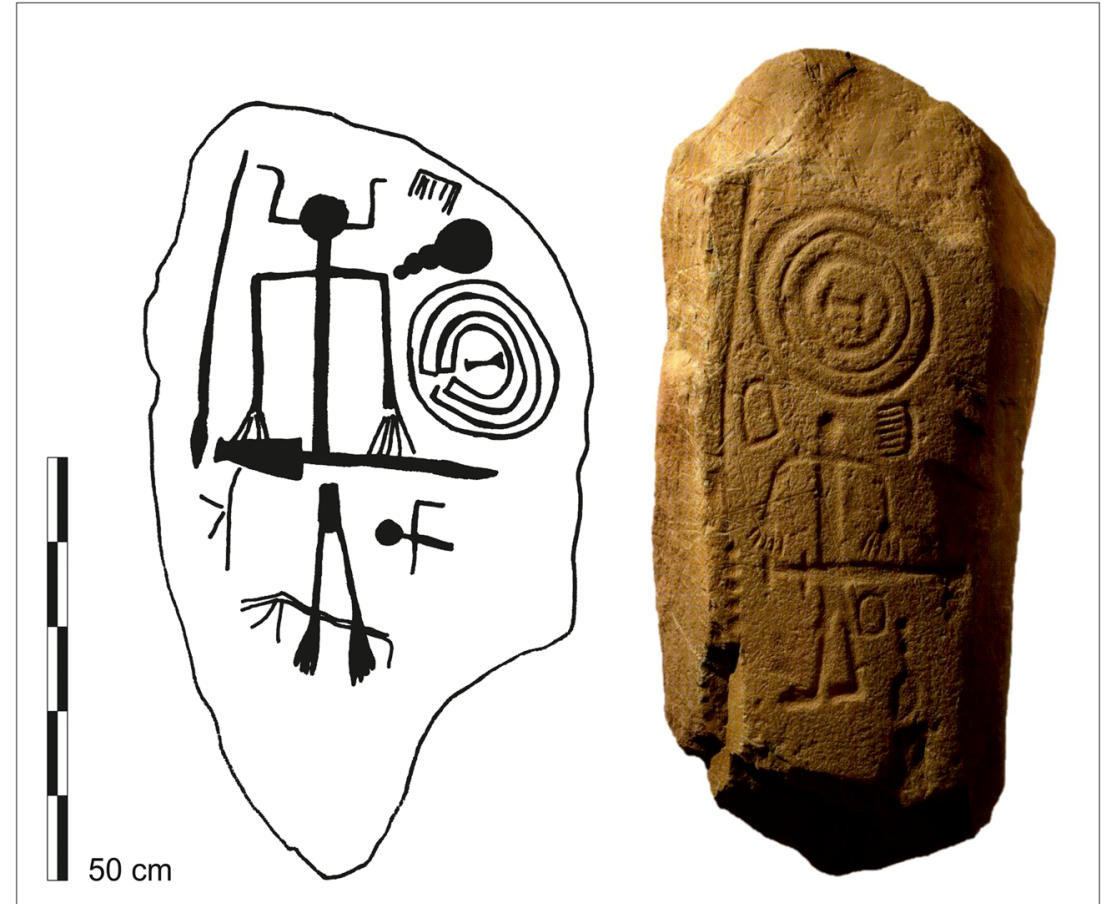

confirms a long-term sequence of use spanning from the LBA (1400/1250-840/820 cal BCE), throughout a transition phase into the IA (840/820-770/750 cal BCE), and until the full 'Orientalizing' period (c. post-770/750 cal BCE), although funerary activities seem to have been less intense during the LBA than in the EIA (Brandherm and Krueger 2017, pp. 311-312). Some sherds of painted wheel-thrown pottery were recorded at Mirasiviene, indicating some activity during the 'Orientalizing' period. Nonetheless, the presence of hand-made biconical urns, dated to between the 12th and the mid/late-8th centuries cal BCE in Setefilla, as well as a hand-made à chardon urn, indicate that activity at Mirasiviene also took place during the LBA and the transition to the IA. This would fall within the most plausible time span for the manufacture of warrior stelae (c. 1400/1250850/750 cal BCE) (Díaz-Guardamino 2012).

That the Mirasiviene stela could have been manufactured where it was found is plausible given the range of stone tools recorded at the site and the nearby availability of loose mica-

Table 4 Archaeological material recorded through fieldwalking at the Mirasiviene stela findspot

\begin{tabular}{lll}
\hline & Total & Charred \\
\hline Pottery & 6382 & 87 \\
Lithics & 67 & \\
Slag & 9 & \\
Bone (animal) & 9 & 4 \\
Fossil & 2 & \\
Metal & 1 & \\
Glass & 1 & \\
Total & 6471 & 91 \\
\hline
\end{tabular}

schist boulders. As mentioned above, ground stone tools and hammer stones made of various hard rocks (e.g. quartzite, diabase) (e.g. Fig. 16) and chipped flint were recorded during the survey. These tools could have been used for shaping the slab as well as pecking and abrading its surface, although of course they may have had wider purposes. Whilst the specific 'hardness' of this type of mica-schist and the stone tools recovered still needs to be determined through field and lab tests - something we intend to pursue in the near future - flint, quartzite or diabase are generally considered 'hard' or 'very hard' rocks in the Mohs scale (6-7), and schist can be classified as 'medium' or 'hard', depending on its mineralogical composition (3-5 in the Mohs scale). A replication experiment conducted at the site using stone tools of quartzite, flint and diabase, amongst others, to create rock art carvings akin to those found on warrior stelae on two mica-schist boulders demonstrated that tools of these materials have the capacity to scratch and carve the surface of mica-schist boulders by repeated percussion (Díaz-Guardamino 2019). Ground stone tools and mining hammers were found at the Setefilla necropolis, although they were held as evidence of other activities (Aubet 1997).

More difficult to assess are the activities producing the wealth of pottery documented at Mirasiviene. Since the bedrock is very close to the surface, tractor ploughing activity destroyed the archaeological deposits of the site, bringing archaeological materials to the surface. Whilst the pottery recorded at the site indicates persistent activity throughout centuries, there is an assemblage of fragments of bowls, plates and urns that shows comparable traits to those from the tumuli $\mathrm{A}$ and $\mathrm{B}$ at Setefilla in terms of fabric, manufacturing 
Fig. 13 Distribution of ceramic sherds in the findspot of the Mirasiviene stela, based on kernel density analysis

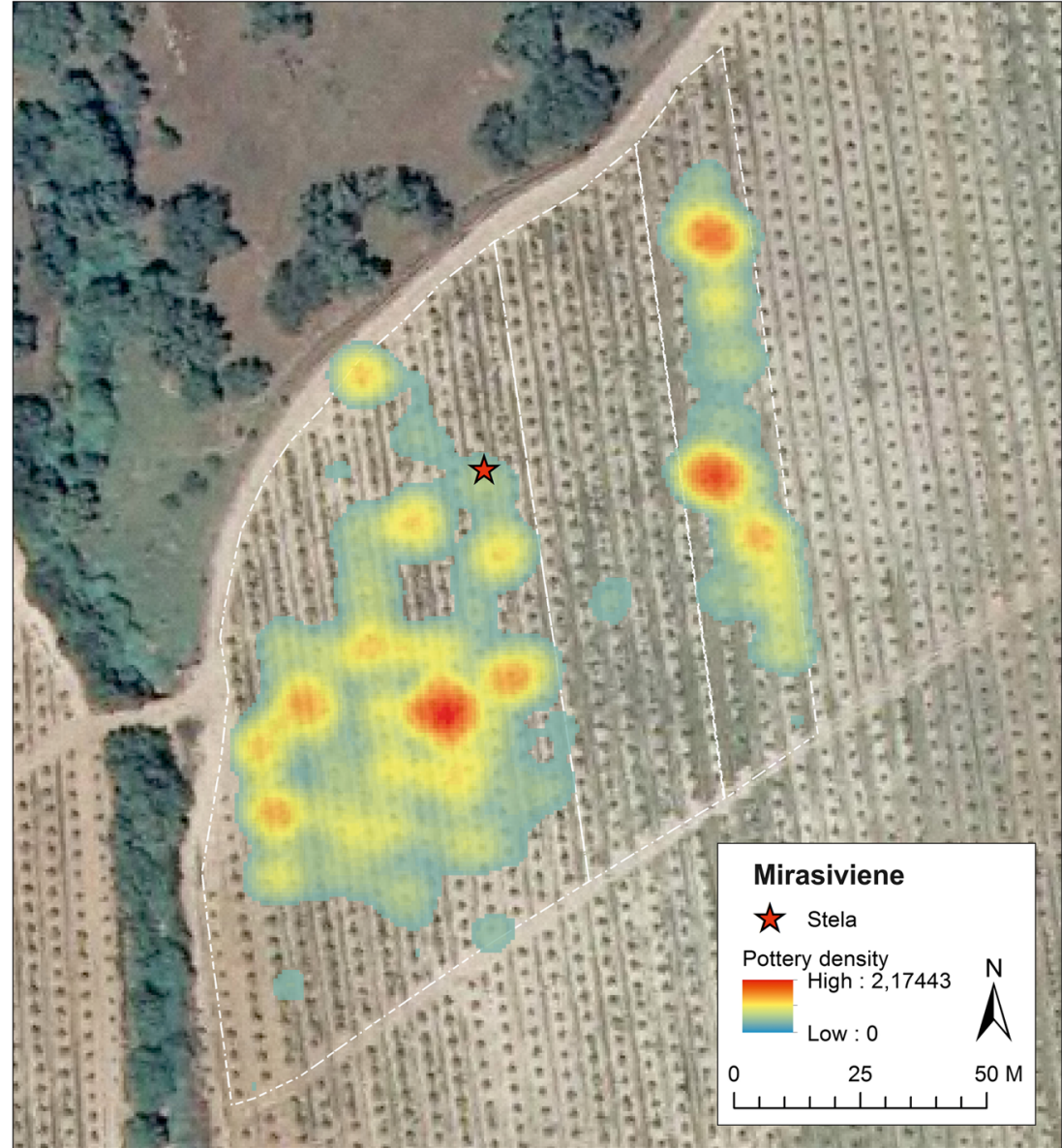

techniques, vessel forms and surface treatments. This not only suggests that there was activity at the site when the stela was made and erected but also that this activity could have been ritual (perhaps mortuary). It is difficult to estimate the number of vessels that could have been part of these depositions, and how this compares to the amount of pottery documented at Setefilla's tumuli. If we consider only the hand-made pottery recovered at Mirasiviene, which can be securely considered prehistoric, the 90 rim fragments recovered could be indicating a discrete number of vessels as most of these are small fragments (c. $4 \mathrm{~cm}$ in width) of vessels of c. $30 \mathrm{~cm}$ diameter, when this can be estimated. We should also bear in mind that most of the fragments recorded at the site belong to walls and are either hand-made or of undetermined manufacture. At Setefilla, the base of tumulus B yielded 30 urns and several plates and bowls, but as radiocarbon dating reveals, the span of deposition is long and, therefore, the amount of pottery belonging to the earliest funerary deposition was smaller and perhaps comparable to the amount of prehistoric pottery documented at Mirasiviene. There is no evidence to suggest that the activity around the Mirasiviene stela was domestic. In fact, our fieldwork led to the discovery of a Bronze Age settlement barely $800 \mathrm{~m}$ to the north of the stela findspot (see below). This suggests that Mirasiviene may have been spatially organised just like Setefilla: a settlement on a hilltop dominating the Guadalquivir River lowlands, and a necropolis (with a stela), right at the contact (liminal) zone between the mountains and the valley. The large amounts of pottery collected at the Mirasiviene stela findspot may well be connected to offerings in vessels - if not cremations - as may be suggested by some of the charred materials registered at the site.

Setefilla was persistently used as a mortuary site for almost two millennia, from the early second millennium cal BCE to Antiquity (Aubet 1975, 1978, 1997, p. 167, 2009, p. 84). Its necropolis includes various tumuli, some of them covering large monumental burial chambers (these dated to the EIA, eighth to sixth centuries $\mathrm{BCE}$ ), and a series of isolated flat graves dated to the IA, as well as six Roman graves. As mentioned above, a warrior stela was reused to cover one of the IA graves. ${ }^{5}$ The abovementioned tumuli $\mathrm{A}$ and $\mathrm{B}$, thought to correspond to different kin-related groups, covered several

\footnotetext{
${ }^{5}$ Recent publications (Aubet 1997: Lam. 1; Diaz-Guardamino et al. 2015, p. 43) mention that, when discovered, the stela was positioned lateral wards, with its decoration visible on the side, as it can be seen in the picture published by Bonsor and Thouvenot (1928, Fig. 26), but these authors mention in the figure caption that the stela was found 'face down on the ground'. Whilst they did not specify if it was the decorated face the one positioned upside down, this is possibly what they meant.
} 

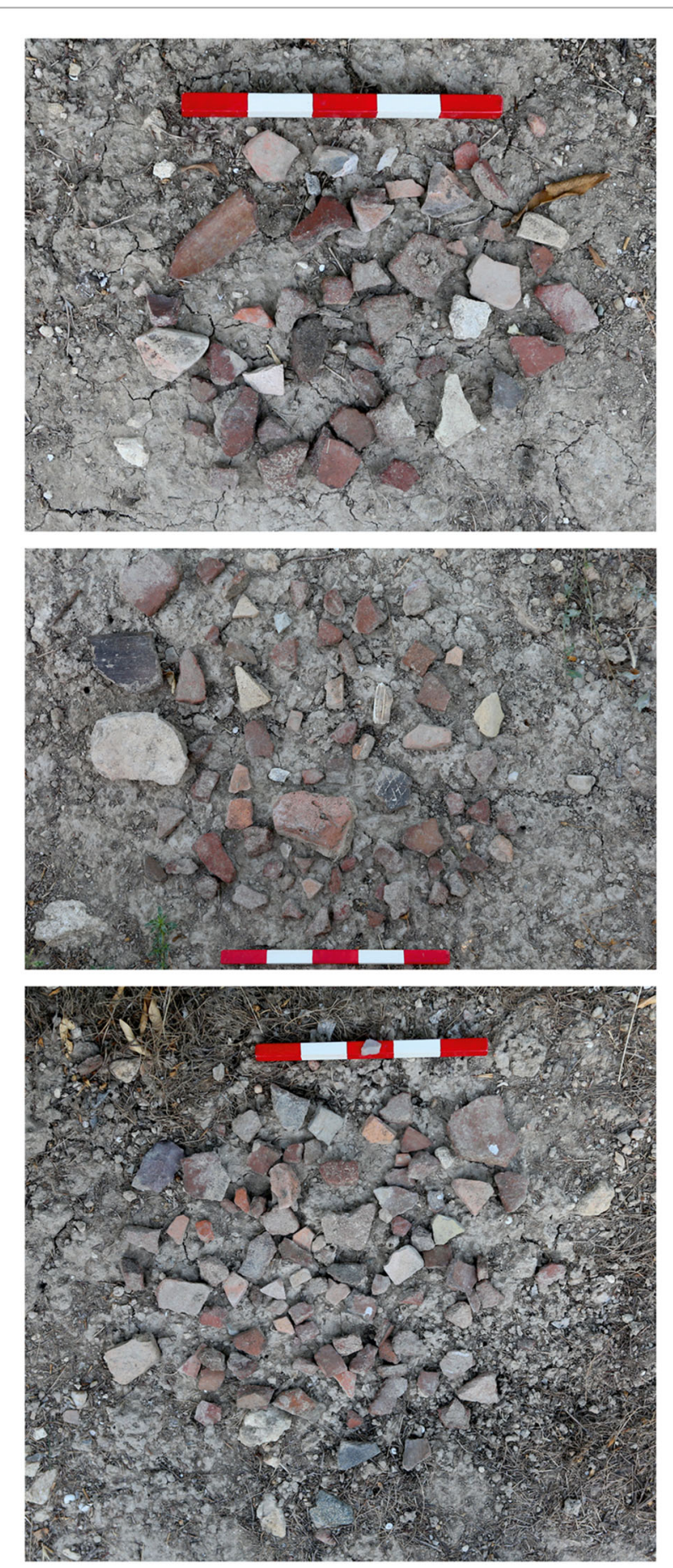

Fig. 14 Photographs taken in the field as part of the fieldwalking recording strategy where the degree of fragmentation can be appreciated. From top to bottom, locations (point Ids) GPS0178 (including analysed ceramic samples 87-90), GPS0189 (incl. samples 24, 25, 34, 41, 93), and GPS0176 (incl. samples 6, 7, 43, 69-76)

pits containing urn-cremations which were commonly surrounded by plates or bowls presumably containing offerings (Aubet 1975, 1978). Tumulus A was subsequently covered by a large EIA tumulus containing a burial chamber.
Table 5 Lithic

assemblage recorded

through fieldwalking at

the Mirasiviene stela

findspot

\begin{tabular}{ll}
\hline Lithics & Number \\
\hline Flint nodule & 10 \\
Chipped flint & 42 \\
Polished & 3 \\
Hammer & 3 \\
Grinding stone & 9 \\
Total & 67 \\
\hline
\end{tabular}

Marking the perimeter of tumulus A, eight 'plain' stelae (c. $1 \mathrm{~m}$ tall, made of 'non-local' rock) with levelled surfaces were found (Aubet 1975, pp. 64-65), whilst one more 'plain' stela was found in the proximity of tumulus B (Aubet 1978, p. 168). The recently published radiocarbon chronology for the urn-cremations of tumuli A and B at Setefilla dates them to the LBA and EIA (Brandherm and Krueger 2017), suggesting that the Setefilla warrior stela was originally associated with the tumuli.

In order to shed some light on the chronology of this association, thus providing a clue to the chronology of the neighbouring Mirasiviene stela, we carried out a Bayesian model of the 27 radiocarbon determinations available for the Setefilla tumuli A and B, all obtained from samples of cremated human bone with the exception of one (sample UBA27571), which was of animal bone (Brandherm and Krueger 2017). As it is well known, in the interval between c. 760 and $400 \mathrm{cal}$ BCE, the calibration curve is consistently flat- the 'Hallstatt plateau'-hence causing chronological intervals to be ample for all samples dating to that time period. Despite this, and the deficient stratigraphic information available (Brandherm and Krueger 2017, p. 307), Bayesian modelling can be used as a proxy to assess the start and end of the Setefilla burial ground activity and, indirectly, for the chronology of the earliest use and subsequent reuse of the warrior stela found in the necropolis. In addition, Bayesian modelling of multiple radiocarbon dates minimises the statistical 'noise' inherent to probability distributions in calibrated dates, hence adjusting results in comparison with more 'standard' calibration of individual dates.

Our Setefilla model (Fig. 21) has been elaborated with OxCal v.4.3.2 (Bronk Ramsey 2017) using the latest corrected calibration curve, IntCal13 Marine Atmospheric (Reimer et al. 2013). The model includes a single phase with all $14 \mathrm{C}$, based on the simultaneity of both tumuli A and B. According to this model, burial activity would have started between 1226 and $1018 \mathrm{cal} \mathrm{BCE}(2 \sigma)$ and ended between 365 and $222 \mathrm{cal} \mathrm{BCE}$ $(2 \sigma)$. Secondly, the Span function has been used in order to assess the duration of the proposed single phase (Fig. 22). The result suggests that the Setefilla burial activity lasted for a period of between 660 and 860 years $(2 \sigma)$.

The landscape setting, spatial organisation of the settlement and stela, as well as the pottery technology, suggest that 
Fig. 15 Distribution of ground and chipped stone tools found at the Mirasiviene stela findspot

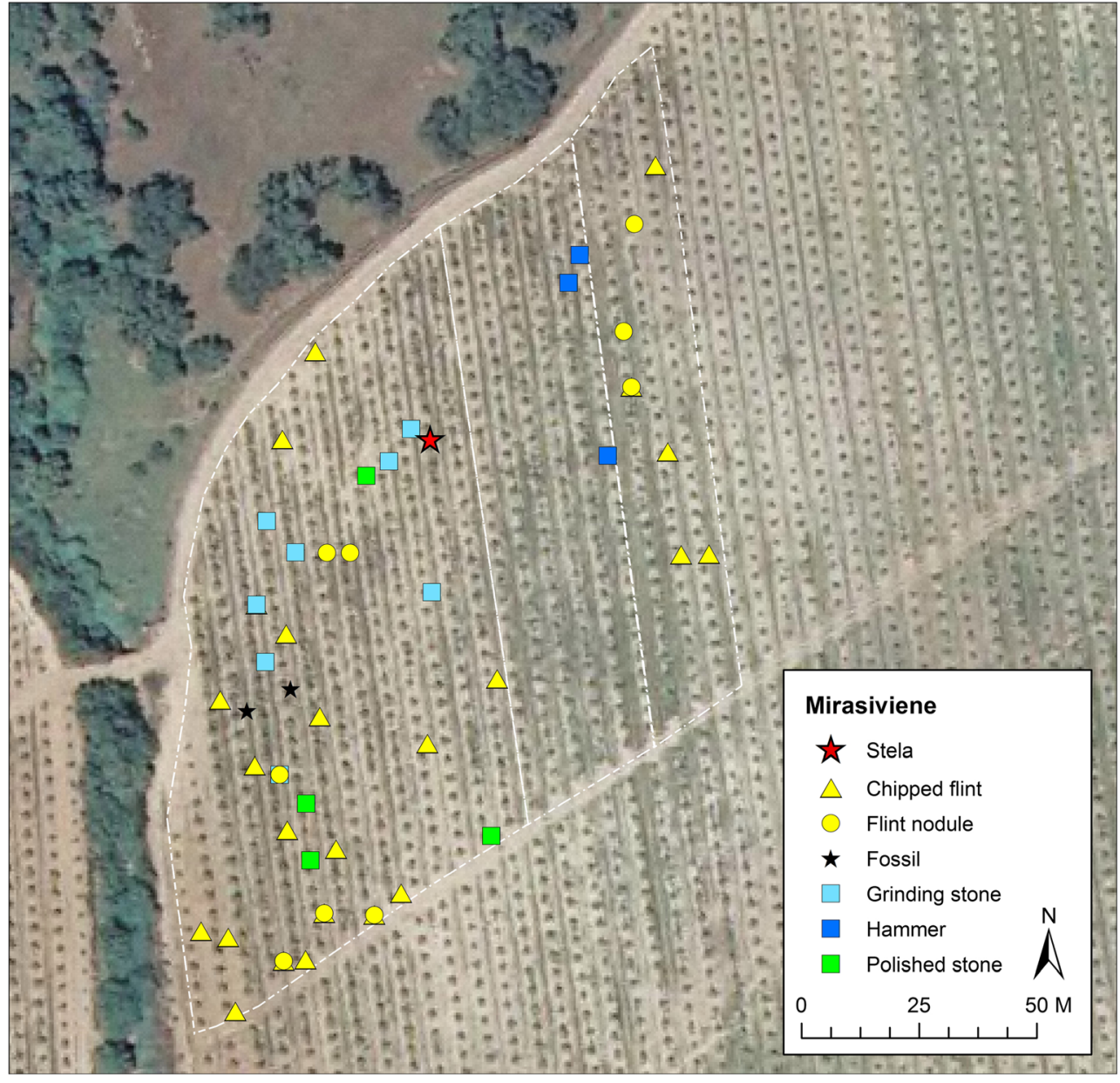

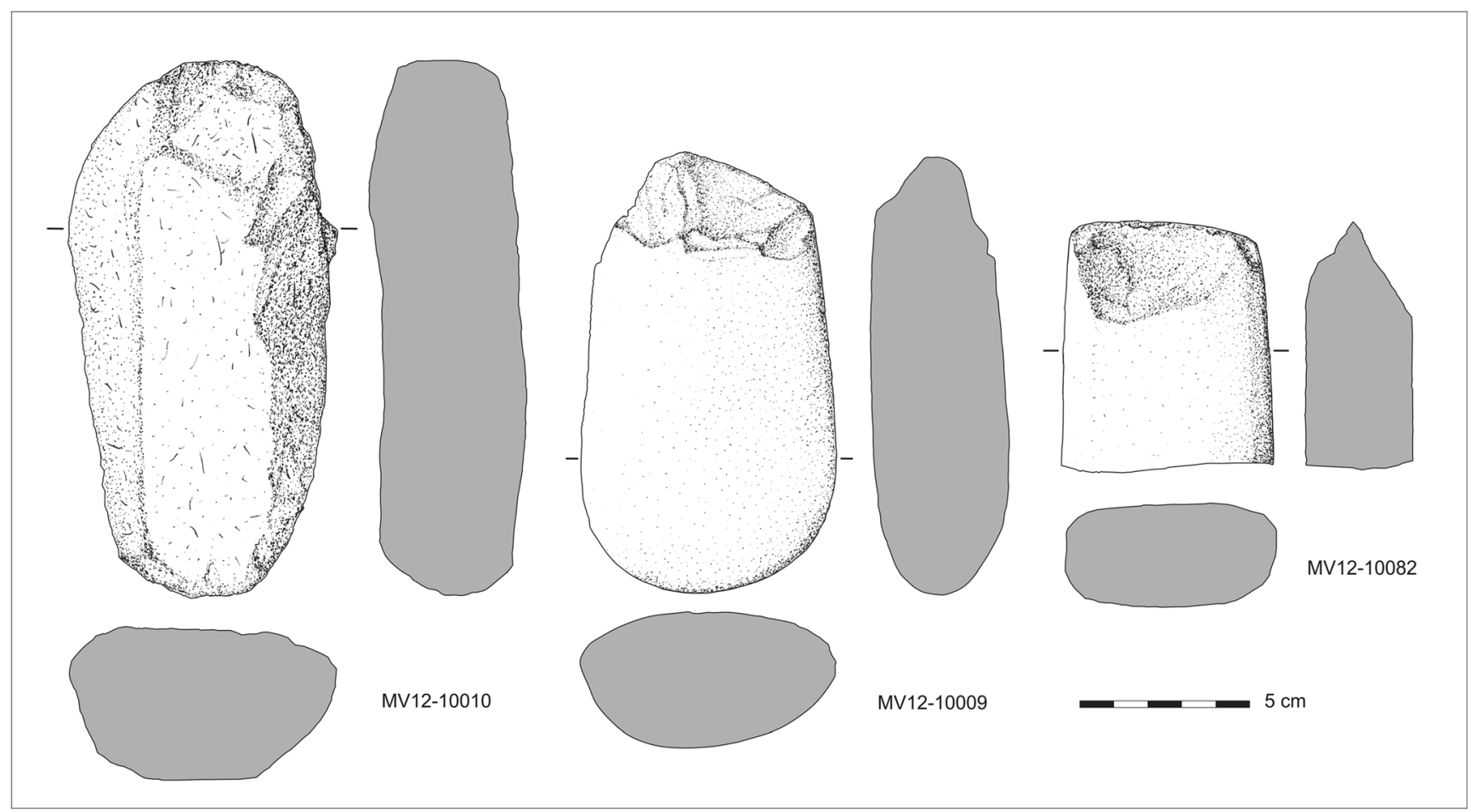

Fig. 16 Ground-edge stone tools (left: dolerite; centre and right: quartzite) found at the Mirasiviene stela findspot 
Fig. 17 Distribution of bone, metal artefacts and slag recorded at the Mirasiviene stela findspot

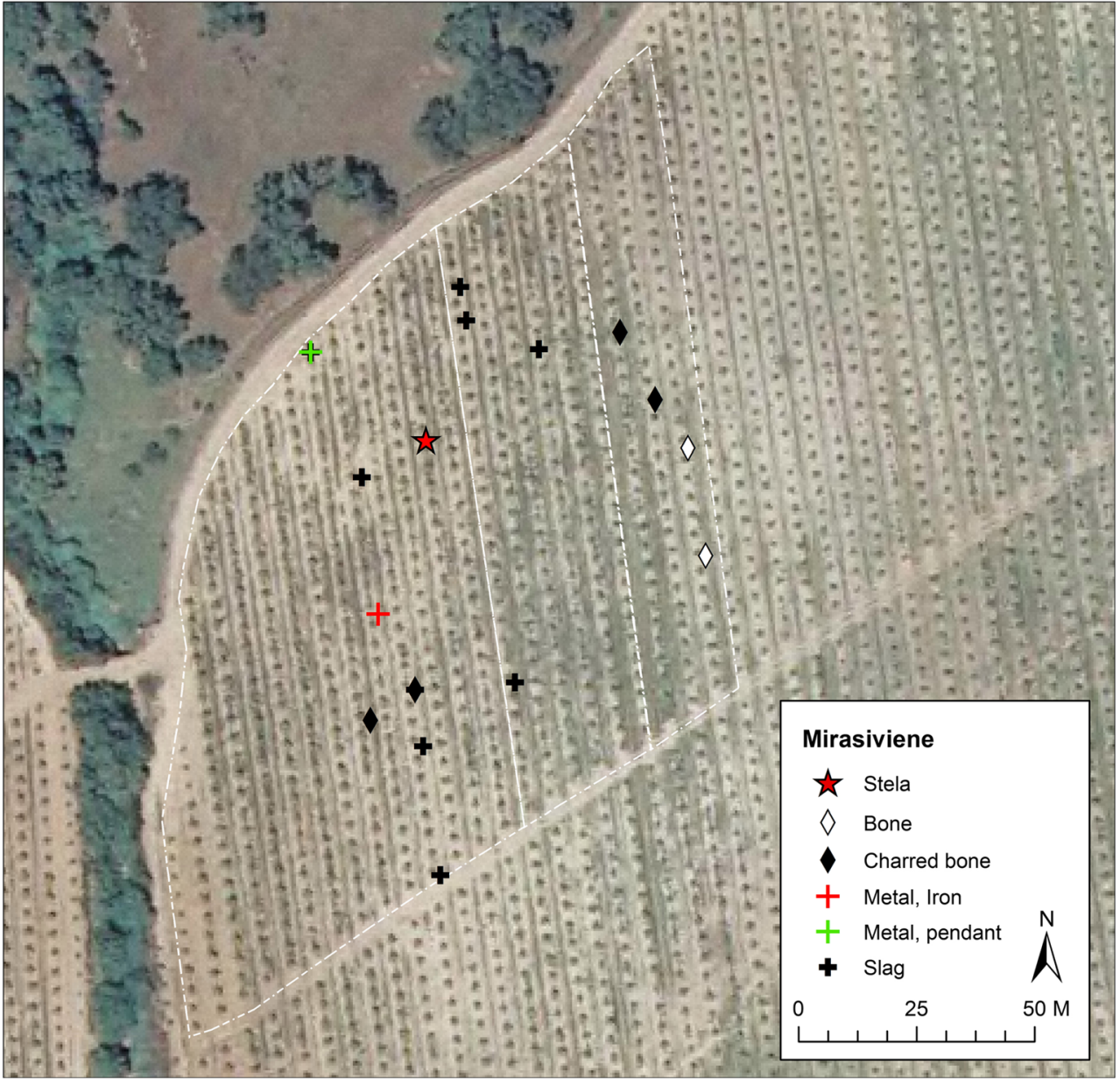

Mirasiviene is likely to have been very similar to Setefilla in the LBA and the transition to the EIA, with offerings' deposition, although at a smaller scale, perhaps not necessarily in connection to cremations but in association with the stela.

\section{Landscape setting: settlement boundaries and sacred spaces}

\section{The Mirasiviene settlement}

As mentioned above, our fieldwork at Mirasiviene revealed a settlement on a hilltop located $800 \mathrm{~m}$ to the north of the stela findspot (Fig. 23). Most of its surface is covered by holm oaks but, despite this, several dry-stone structures were readily visible and georeferenced with GPS. These include remains of walls outlining an enclosure at the top of the hill (c. $3200 \mathrm{~m}^{2}$ ). Attached to the SE side of the enclosure, with a central position on the top of the hill, were remains of a large central circular structure (c. $22 \mathrm{~m}$ of diameter; possible watch-tower or bastion?). Two further circular stone structures (3-3.5 m diameter) were recorded inside and outside of the enclosure, as well

as further semi-circular structures scattered throughout the southwestern slope of the hill, outside the enclosed area. The site is located at the foothills of the Sierra Morena, commanding extensive views towards the Guadalquivir valley. From this site, the Mirasiviene stela findspot is clearly visible, as well as the necropolis and settlement of Setefilla (Figs. 24 and 27).

Table 6 XRF results for slagged samples recovered within the Mirasiviene surveyed area

\begin{tabular}{llll}
\multicolumn{3}{l}{$\begin{array}{l}\text { Mirasiviene survey slagged samples. } \\
\text { Oxide wt\% }\end{array}$} \\
\hline Sample & 10315 & 10160 & $\begin{array}{l}1 / 10 / \\
2012\end{array}$ \\
\hline $\mathrm{Al}_{2} \mathrm{O}_{3}$ & 16.70 & 15.06 & 06.87 \\
$\mathrm{SiO}_{2}$ & 66.08 & 75.17 & 41.72 \\
$\mathrm{~K}_{2} \mathrm{O}$ & 01.47 & 01.25 & 01.50 \\
$\mathrm{CaO}$ & 07.53 & 02.23 & 17.92 \\
$\mathrm{TiO}_{2}$ & 01.10 & 01.11 & 00.41 \\
$\mathrm{MnO}$ & 00.21 & 00.16 & 00.48 \\
$\mathrm{Fe}_{2} \mathrm{O}_{3}$ & 06.91 & 05.02 & 30.98 \\
$\mathrm{CuO}$ & nd & nd & 00.13
\end{tabular}


Table 7 Ceramic assemblage recorded through fieldwalking at the Mirasiviene stela findspot

\begin{tabular}{|c|c|c|c|c|c|c|c|c|c|c|}
\hline \multirow[t]{2}{*}{ Pottery } & \multirow[t]{2}{*}{ Frags } & \multicolumn{3}{|l|}{ Decoration } & \multicolumn{5}{|c|}{ Form } & \multirow[t]{2}{*}{ Charred } \\
\hline & & Burnished & Incised & Painted & Rim & Base & Carinated & $\begin{array}{l}\text { Wall/ } \\
\text { indet. }\end{array}$ & Handle & \\
\hline Wheel-thrown & 254 & 3 & 1 & 3 & 57 & 9 & 0 & 186 & 1 & 2 \\
\hline Hand-made & 1873 & 75 & 1 & 5 & 90 & 27 & 20 & 1717 & 18 & 8 \\
\hline Indet. & 4245 & 2 & 1 & 1 & 28 & 10 & 0 & 4215 & 4 & 77 \\
\hline Total & 6382 & 80 & 3 & 9 & 175 & 46 & 20 & 6118 & 23 & 87 \\
\hline
\end{tabular}

The significance of this site became clear as we detected some concentrations of pottery sherds with prehistoric appearance just outside the enclosure in the southwestern slope, as well as inside the enclosure. Pottery sherds collected at this settlement (Fig. 25) have parallels in the LBA/EIA assemblages of other settlement contexts in the region, including Setefilla (phases 2 and 3, in Aubet et al. 1983, pp. 70-107) (see below), whilst their fabrics correspond to Mirasiviene's pottery groups I/A-C (52\% of the sample), (similar to Setefilla's class I, $21 \%$ of the sample), made of locally sourced clays (see above). The pottery recorded includes fragments of large containers (Fig. 25: S08, a possible hand-made à chardon urn), one with an application for suspension (Fig. 25: 58). There are also various rims of bowls, a wall fragment of a carinated bowl (Fig. 25: 83) and an artefact whose functionality is difficult to discern but which looks like a base (Fig. 25: S10) of an artefact devised to hold containers.

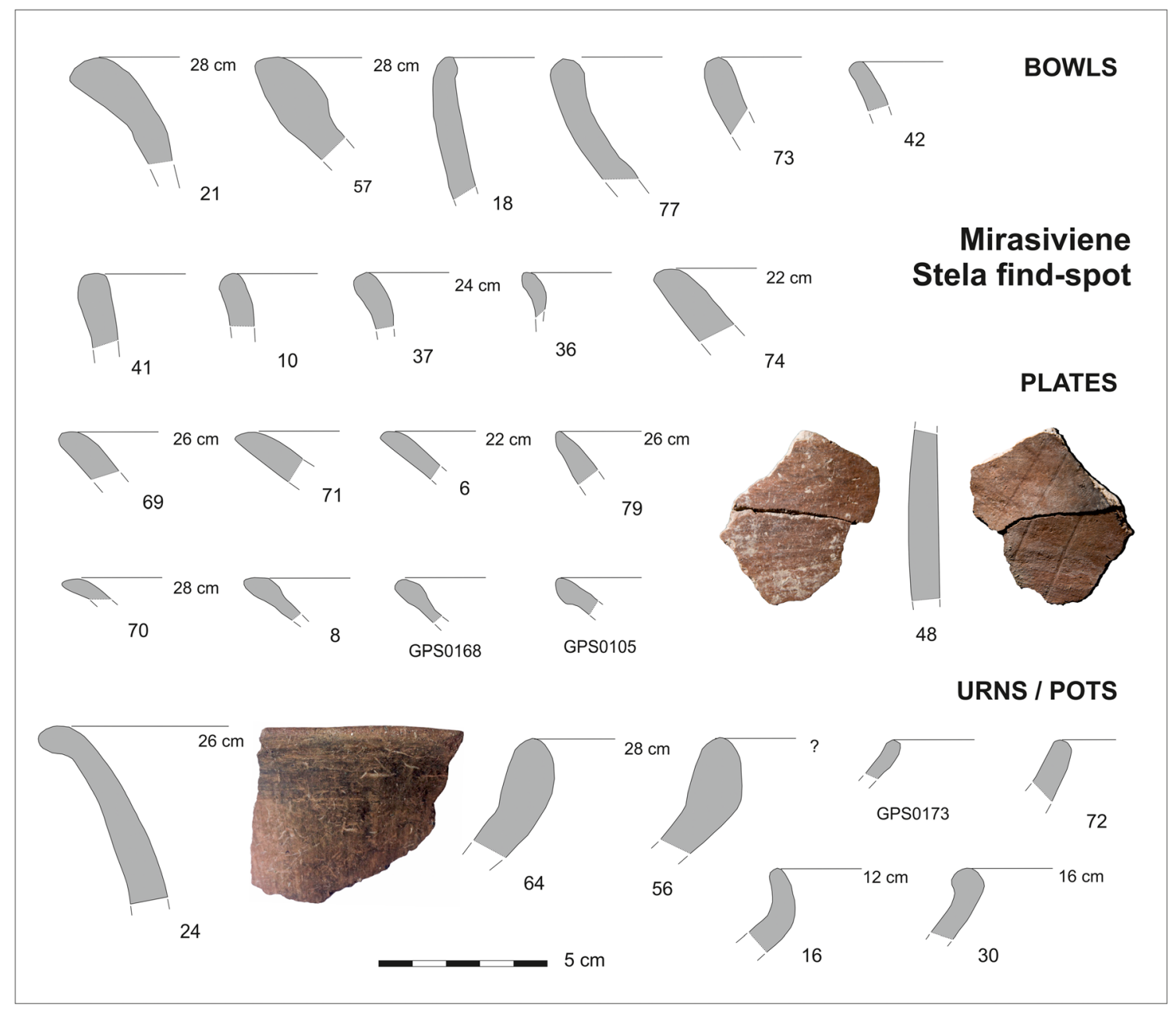

Fig. 18 Ceramic sherds documented at the Mirasiviene stela findspot 


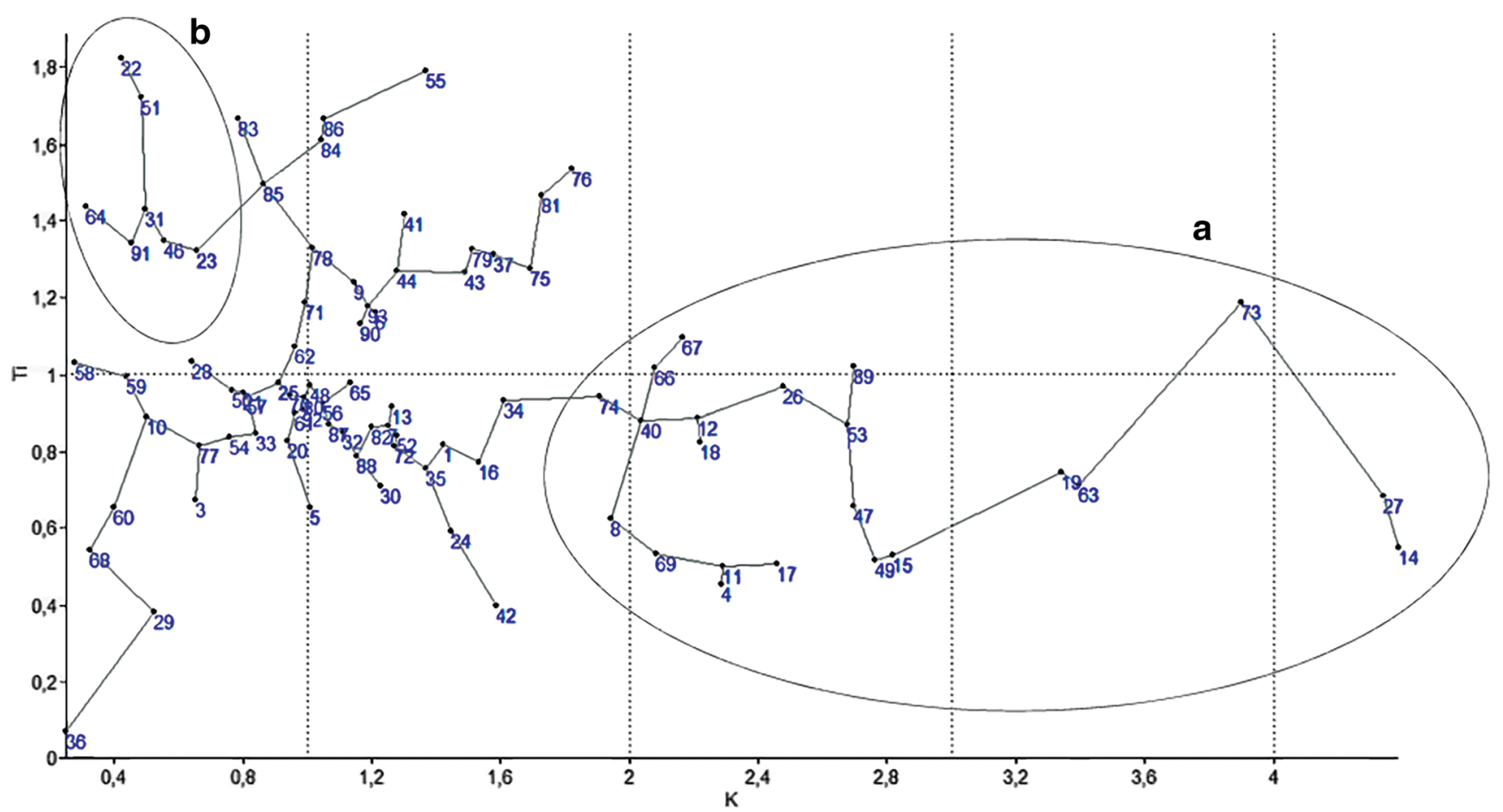

Fig. 19 Minimum spanning tree of 89 ceramic samples from the Mirasiviene stela findspot. The axes are plotted in percentage

Table 8 Classes and groups distinguished by means of petrographic analysis of the samples collected at the stela findspot and settlement of Mirasiviene, including description of characteristics and samples attributed to each

Class Group Characteristics Samples

I A (= group II It consists of ferruginous clay with iron oxide concretions and ferruginous rock Setefilla) fragments as one of the dominant ingredients. The clay matrix might be characterised as very heterogeneous and rich mostly in grains of quartz and feldspar, muscovite and dark, hard shinning minerals (hornblende, schorl?). Sporadically shale, biotite, iron nodules and some unidentified rock fragments (gabbro or basalt?) occurred. Moreover, there were some visible white minerals in notable quantity (probably albite). In one sample, a grain of grog was detected, which might have been accidentally added to the clay matrix. The shape of the grains is mainly sub-angular and sub-rounded, and their size varies from 0.1 to even $2.5 \mathrm{~mm}$ length. Total quantity of non-plastic inclusions was high and recorded as 30-35\%. The clay matrix was porous, and sorting was moderate to bad. Some organic fibres were observed in some of the analysed sherds; however, the quantity was low (around 5-7 vol\%) and might have been results of necessity to increase the plasticity of clay. The colour of the matrix differs from red (2.5 YR 4/6; 5/6; $4 / 4 ; 3 / 6 ; 5$ YR 4/6) to yellowish red (5 YR 4/6).

$\mathrm{B}$ (= group This group is like group A and contains a lot of iron oxide concretions, but the III quantity of quartz and feldspar significantly decreased. The dominant Setefilla) inclusions are composed of rock fragments (probably gabbro, diabase or basalt). The other found components are biotite, hornblende and rarer calcite, olivine and lime nodule. Grain shapes are mostly sub-angular, and their size does not usually exceed $1 \mathrm{~mm}$ but occasionally reaches $4 \mathrm{~mm}$. Matrix has porous structure with many cracks. Some of them have already left after burning out of organic fibres which are present in quantity lower than $5 \mathrm{vol} \%$. Sorting is mostly bad, and grains occur in quantities from 25 to $35 \%$. The colour of the matrix oscillates between dark grey (7.5 YR 3/1), dark brown (7.5 YR 3/2, 4/2, 4/3), dark reddish brown (5 YR 3/2, 4/2, 4/3, $4 / 4 ; 2,5 \mathrm{YR} 4 / 4)$ and red (2.5 YR 3/2,4/2), often with visible lighter core (2.5 YR 4/6; 5YR 3/1). 
Table 8 (continued)

\begin{tabular}{|c|c|c|c|}
\hline Class & Group & Characteristics & Samples \\
\hline & & $\begin{array}{l}\text { also grains of biotite, iron oxide concretions, muscovite and occasionally } \\
\text { also small amount of organic fibres were recorded. Grains are mostly } \\
\text { sub-angular and sub-rounded, and their size is between } 0.1 \text { and } 2.5 \mathrm{~mm} \text {. } \\
\text { Total quantity of non-plastic inclusions is estimated to be } 20-30 \% \text { with } \\
\text { normal, but porous structure of the matrix and moderate sorting. The length } \\
\text { of the fibres was } 0.1 \text { to } 1 \mathrm{~mm} \text {. The variety of colour tones detected were } \\
\text { from reddish brown ( } 2.5 \mathrm{YR} 4 / 3 \text { ) to very dark grey ( } 5 \text { YR } 3 / 1 ; 7 / 5 \text { YR } 4 / 1 \text { ), } \\
\text { sporadically with distinctive core ( } 5 \text { YR } 4 / 2 \text { dark reddish grey; } 2.5 \text { YR } 4 / 4 \\
\text { reddish brown) and margins ( } 2.5 \text { YR } 4 / 6 \text { red; } 2.5 \text { YR } 3 / 1 \text { dark reddish grey). }\end{array}$ & \\
\hline II & $\begin{array}{l}\text { D (= group } \\
\text { VB } \\
\text { Setefilla) }\end{array}$ & $\begin{array}{l}\text { This group is characterised by calcareous clay with numerous grains of } \\
\text { limestone and calcite. Quartz and iron oxide are also commonly present. } \\
\text { Sporadically, other components such as lime nodules, biotite and feldspar } \\
\text { and very rare sandstone occurred. The shape of the grains is usually } \\
\text { sub-rounded and sub-angular, and the quantity of these elements varies from } \\
10 \text { to } 15 \% \text {. The matrix is rather compact compared to other groups with } \\
\text { moderate sorting of non-plastic inclusions which ranges from } 0.1 \mathrm{~mm} \text { (and } \\
\text { smaller) to } 1 \mathrm{~mm} \text { in some cases. Moreover, there were additional small } \\
\text { amounts of organic fibres (around } 5-7 \text { vol\%) and } 0.1-0.3 \mathrm{~mm} \text { length (oc- } \\
\text { casionally reaching } 1 \mathrm{~mm} \text { ). The colour of the clay matrix is light and gently } \\
\text { varies from pink (7.5 YR 7/3, 7/4;2.5 YR 6/6;5 YR 7/4) to light brown }(7.5 \\
\text { YR 6/3) and light grey }(7.5 \mathrm{YR} 6 / 1) \text {. }\end{array}$ & $4,11,15,26,49,63$ \\
\hline III & $\begin{array}{l}\text { E (= group } \\
\text { VIII } \\
\text { Setefilla) }\end{array}$ & $\begin{array}{l}\text { The group consists of rather sandy clay with numerous grains of quartz (mostly } \\
\text { transparent and milky) and feldspar (also albite). Iron oxide concretions, } \\
\text { lime nodule, muscovite and biotite as well as some grains of calcite and } \\
\text { organic fibres are present. Matrix is considered as compact to normal with } \\
\text { open pores as a result of adding organic matters to clay, which were burnt out } \\
\text { during firing of sherd. Sorting is moderate, and the size of the inclusions is } \\
\text { diversified and varies from less than } 0.1 \text { to } 1 \mathrm{~mm} \text {; however, few bigger } \\
\text { grains are visible as well. The total quantity of the grains is estimated to be } \\
35-40 \% \text {. Their shape is both sub-rounded and sub-angular. The size of } \\
\text { organic matters is limited to } 0.3 \mathrm{~mm} \text { and their quantity does not exceed } \\
10 \text { vol\%. Colour is dark grey ( } 5 \text { YR } 3 / 1 ; 7.5 \text { YR 4/1), but in a few cases, the } \\
\text { margins }(5 \text { YR } 4 / 2 \text { ) differ from the core }(5 \text { YR } 4 / 1) \text {. }\end{array}$ & $14,53,30,27,24,89,67,61$ \\
\hline & $\mathrm{F}$ & $\begin{array}{l}\text { This group shows similarity to group E, but quartz dominates over feldspar and } \\
\text { other inclusions. Muscovite, biotite, hornblende and iron oxide concretions } \\
\text { sporadically occurred, but some single grains of limestone, sandstone and } \\
\text { olivine as well as some unidentified rock fragments were also noticed. The } \\
\text { shapes of the grains, which occur in quantities of } 35-45 \% \text {, are mostly } \\
\text { sub-rounded and rounded. Whilst sorting is moderate, the matrix is normal, } \\
\text { and it is assumed that the added inclusions were selected deliberately, as } \\
\text { their significant homogeneity indicates. Sporadically, organic fibres were } \\
\text { visible in the clay matrix, but their amount is small (c. } 7 \text { vol\%) and left holes } \\
\text { are relatively tiny }(0.1-0.3 \mathrm{~mm}) \text { with few bigger fragments reaching } 1 \mathrm{~mm} \\
\text { length. Greyish core }(10 \mathrm{YR} 5 / 1 \text { grey) is distinctively different in colour than } \\
\text { reddish margins }(2.5 \mathrm{YR} 5 / 8 ; 5 \text { YR } 5 / 6,5 / 8) \text {. }\end{array}$ & $19,47,54$ \\
\hline & G & $\begin{array}{l}\text { This group includes only two samples, which contained mostly quartz and tiny } \\
\text { organic fibres and in smaller quantities muscovite, iron oxide concretions, } \\
\text { lime nodule, feldspar and some unidentified white rock fragments } \\
\text { (dolomite?). The shape of the grains is sub-angular, and their size is not } \\
\text { bigger than } 1.5 \text { mm suggesting rather moderate sorting. The matrix is } \\
\text { considered as relatively compact compared to other analysed clays with } \\
\text { some limited amount of open pores. The quantity of non-plastic inclusions is } \\
\text { low (c. } 15 \% \text { ) and organic matters do not reach even } 10 \text { vol\%. The difference } \\
\text { in colour between the core ( } 7.5 \text { YR 4/1; } 10 \text { YR 4/2) and margins ( } 7.5 \text { YR } \\
5 / 2 ; 2.5 \text { YR 4/4) is clear as well. }\end{array}$ & 5,12 \\
\hline
\end{tabular}

The link between the stela, its findspot and the settlement is highly plausible given their proximity, intervisibility (Figs. 26 and 27) and the commonalities found amongst their pottery assemblages. This link is reinforced when we compare their landscape setting to that of the stela of Setefilla, its necropolis and their associated settlement, the Mesa de Setefilla (Aubet et al. 1983). 
Fig. 20 Micro-photographs of ceramic samples from the Mirasiviene stela findspot showing the different fabric groups (A to G) discerned through petrographic analysis

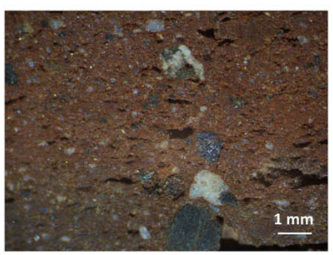

GROUP A
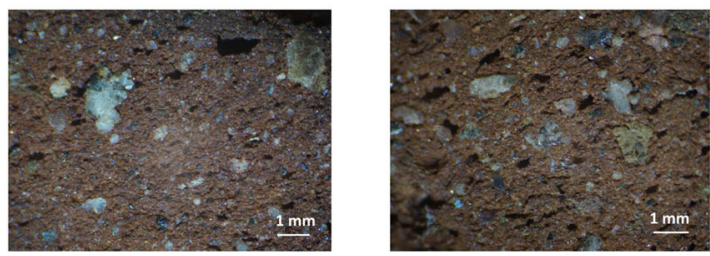

GROUP B
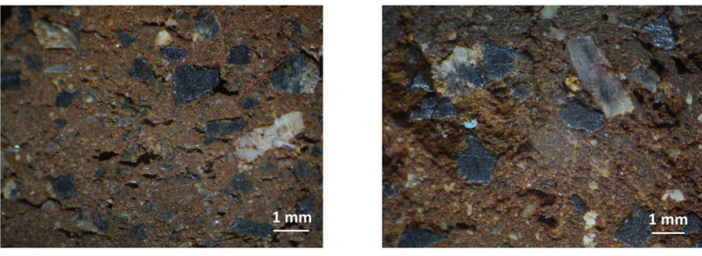

GROUP D

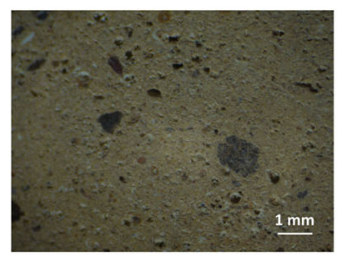

GROUP E

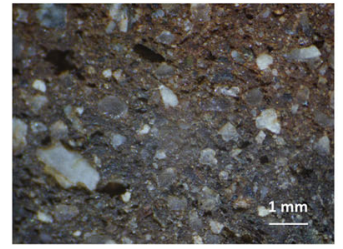

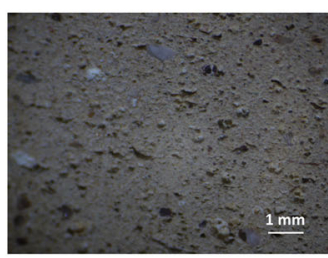

GROUP F

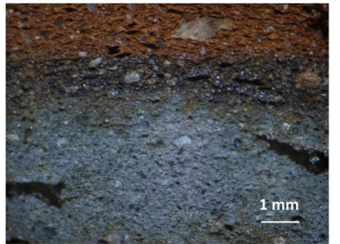

GROUP C
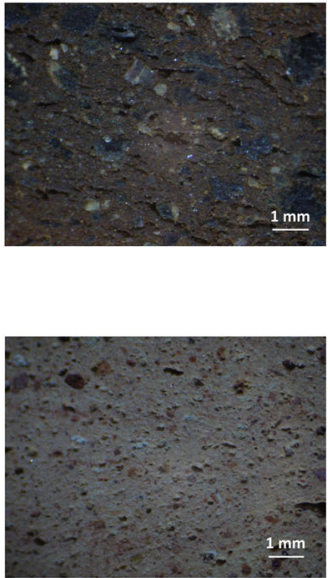

GROUP G

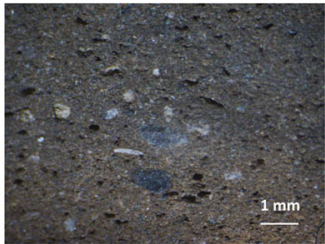

\section{Setefilla: settlement and necropolis}

The Setefilla settlement (Fig. 28) is located $3 \mathrm{~km}$ to the west of Mirasiviene, on a 'mesa' (plateau) with long-term continuous occupation spanning from the Early Bronze Age (before c. nineteenth century cal BCE) (phase 1, with stone enclosure, bastions and stone-base huts) until the end of the Late Iron Age (phase 5), when the site was abandoned ${ }^{6}$ (Aubet et al. 1983). During the LBA (phase 2), possibly the period when the stela of Setefilla was manufactured, the plateau was occupied by dispersed huts made of perishable materials (i.e. mud-wall), being phase $2 b$ contemporary to the earliest urn-cremations documented at the necropolis (Brandherm and Krueger 2017, p. 310), which is located on a gentle hill at the foot of the settlement, $1 \mathrm{~km}$ to the

\footnotetext{
${ }^{6}$ Notably, the site became an important strategic location during the Middle Ages, hosting the Arab fortress of Shadfilah and an associated hamlet. By the thirteenth century $\mathrm{AD}$, the site is occupied by the Catholic religious order of San Juan, who built a church dedicated to Our Lady of the Incarnation, which soon become widely known for its supernatural powers, leading to the construction of a sanctuary in the sixteenth century $\mathrm{AD}$, which still attracts regular pilgrimages.
}

south (Fig. 28). Metallurgical activities (e.g. copper smelting) are first attested at the settlement during phase 2 and are thought to have held some significance (Aubet et al. 1983, p. 79; Hunt 2003, pp. 352-353). Importantly, evidence of (prehistoric) copper ore mining was documented not far from the site $(10-15 \mathrm{~km}$ to the NE and SE), in the Sierra Morena mountain range and the Guadalquivir valley (Hunt 2003, pp. 64, 66-67). Added to these activities, it is thought that cattle raising was also relevant at Setefilla during the LBA and EIA; interestingly, remains of several oxen were found in tumulus A at the necropolis. Some of the pottery types documented during phase 2 at the settlement (e.g. Cogotas pottery (Aubet et al. 1983: figs. 25-26)) and the necropolis (e.g. biconical urns), as well as the warrior stela, reveal that Setefilla was already a well-connected site at the time, with links to the Iberian Central Plateau and the Lower Guadalquivir valley.

During the EIA (phase 3, 'Orientalizing'), settlement activity was also significant, and metallurgical activity, possibly including copper, as well as iron smelting, seems to intensify (Hunt 2003, p. 357); it was during this period when wheelthrown pottery is generalised at the site, an innovation linked to the development of exchange networks with the Phoenician 
Fig. 21 Chronological model for the span of burial activity at the tumuli A and B in the necropolis of Setefilla

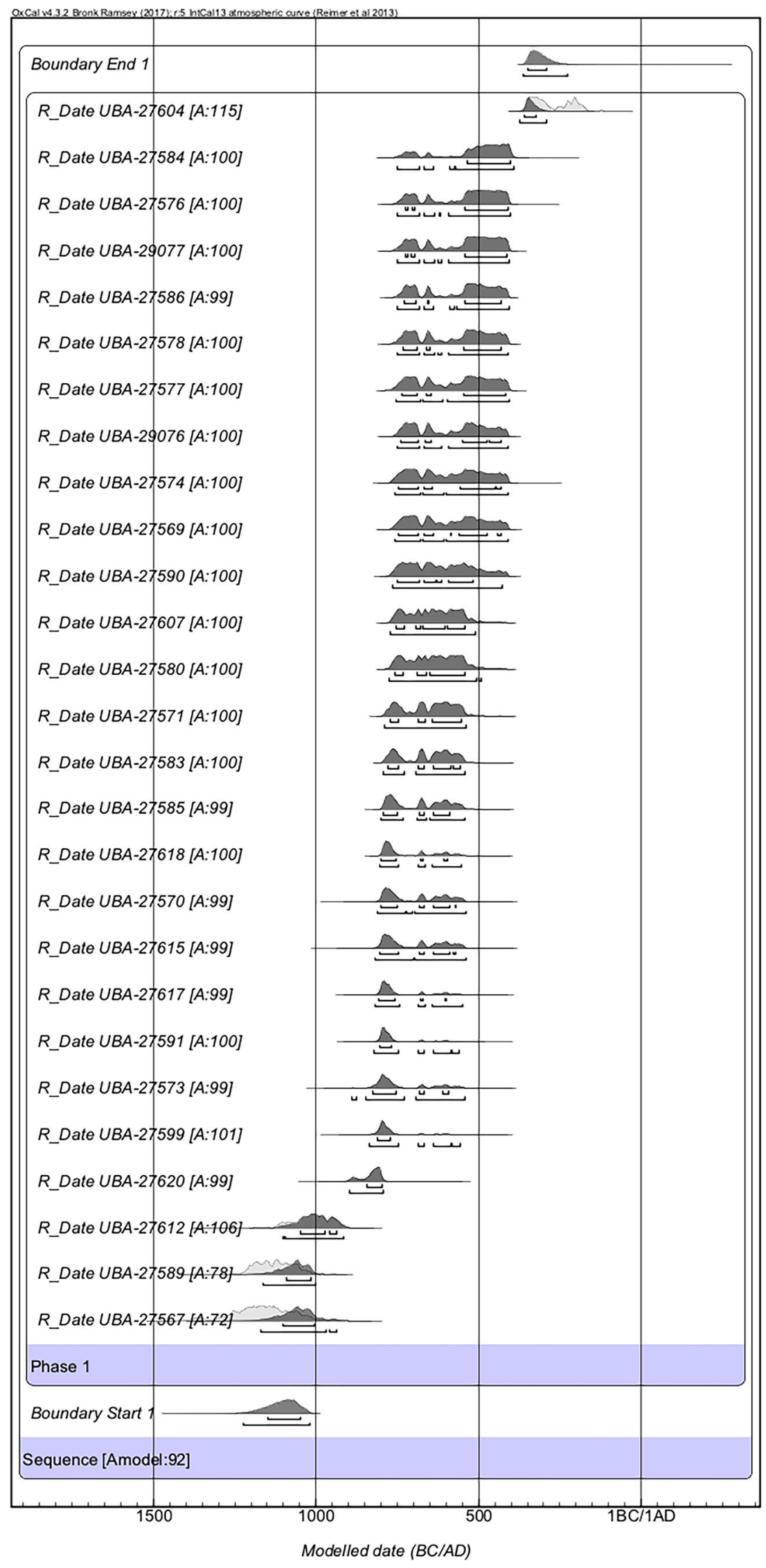




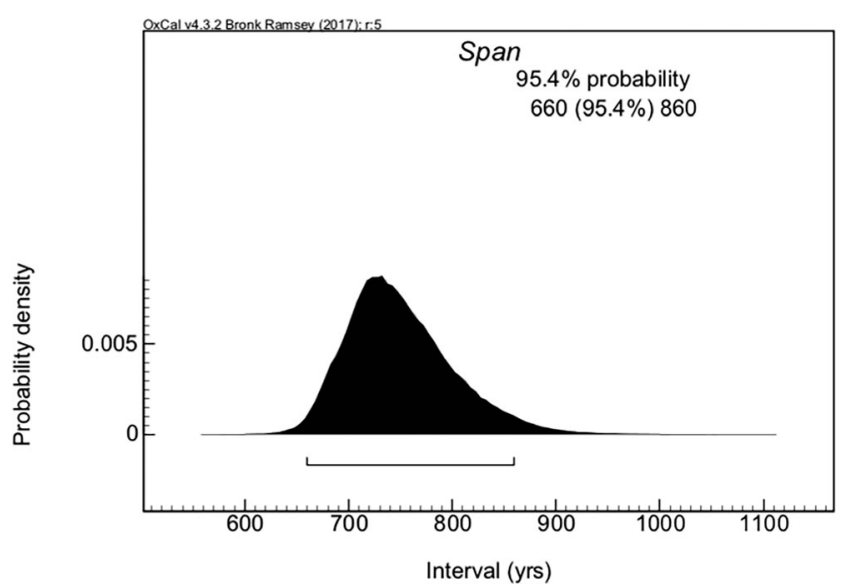

Fig. 22 Probability distribution for the number of years over which burial activity in tumuli A and B at the necropolis of Setefilla took place

settlements of the Atlantic and Mediterranean coasts, although hand-made pottery linked to the previous tradition of potterymaking was still dominant at the site. It is worth noting that both Setefilla and Mirasiviene are located right were the Corbones River meets the Guadalquivir River. The Corbones, which springs at Almargen (Malaga) where significant evidence, including an EIA settlement (Las Madrigueras) and another warrior stela, has been found (Díaz-Guardamino et al. 2019), is the natural corridor connecting the Lower Guadalquivir River and the Malaga coast, where several Phoenician settlements were founded between the ninth and eighth centuries BCE.

The Setefilla settlement must have been an important one. Not only was it located next to the Guadalbarcar River, whose discharge was much higher in the past, before the construction of the José Torán reservoir, situated $1 \mathrm{~km}$ up river, but it is also located next to an important drove way (Vereda de la Carne), whose origin may be traced back to, at least, the Middle Ages. In Setefilla, settlement and necropolis are inter-visible and are located relative to each other in a similar fashion to their counterparts in Mirasiviene, although in the case of Setefilla, settlement and necropolis are separated by the Arroyo del Pilar, a tributary of the river Guadalbarcar, drawing a physical, and perhaps symbolic, boundary between both spaces. Finally, the settlement of Mirasiviene can also be seen from the northern-most and most intensely occupied area of the Setefilla 'mesa' (Fig. 27).
Fig. 23 Location of the Mirasiviene stela findspot and its nearby settlement

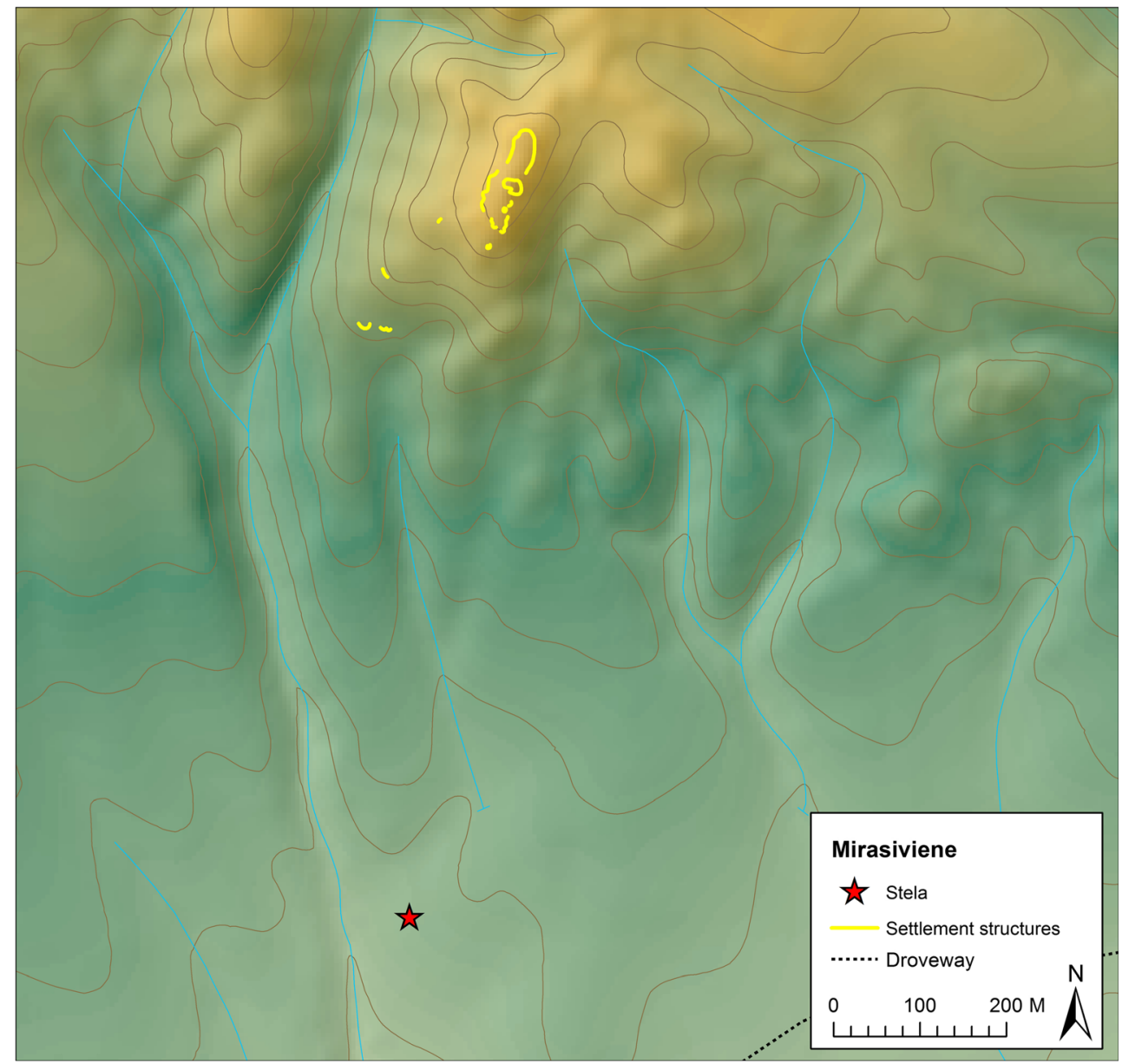




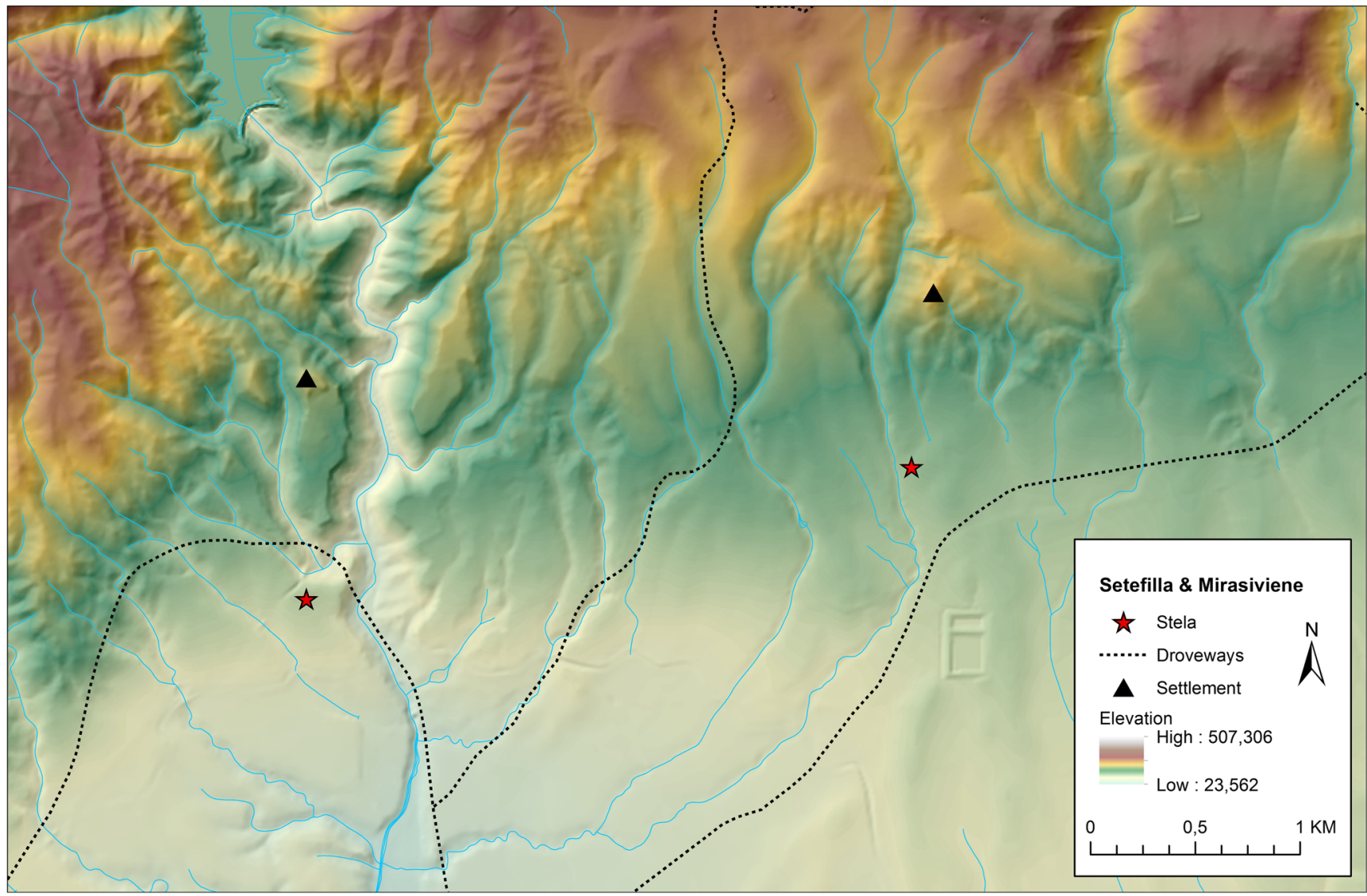

Fig. 24 Location of the Mirasiviene (right) and Setefilla (left) stelae findspots and their associated settlements

\section{Mirasiviene and Setefilla: connected sites}

Mirasiviene and Setefilla mirror each other in many respects. They have similar landscape settings (Figs. 23, 24, 27 and 28), exerting control over passage ways and access to valuable resources, like those found in Sierra Morena (e.g. metal ores (Hunt 2003), lithic resources and pastures, or access to the Guadiana valley and the Iberian Central Plateau) and the Guadalquivir plain (e.g. fertile arable land, some mineral resources or direct connection towards Lands of Antequera and the Mediterranean basin via the Corbones River valley). Both sites may have been closely connected, especially if we consider that they were seemingly active and/or occupied simultaneously: apart from comparable pottery vessel morphologies, most of the fabric groups identified at Mirasiviene correspond well to groups found at Setefilla, and the radiocarbon chronology of the latter fits perfectly the evidence found at the former.

The fact that both stelae were found on the lowlands at a similar distance from their respective settlements-from which they were both visible-suggests that their location could have been part of a broader pattern of association of these monuments with liminal spaces, marking a place of sacred significance located at the outskirts of the settlement. These liminal places were not located at the margins of the catchment area of these settlements - the distance between Mirasivienne and Setefilla indicates that this could have reached c. $1.5 \mathrm{~km}$-but responded to a different logic, perhaps linked to memory and tradition and/or the sacred significance of those specific locales situated closer to the dwelling. The relative location of the Llanete de los Moros settlement in Montoro (Córdoba), occupied during the Copper Age, BA and EIA (Martín de la Cruz 1987, 1988), and the recently studied epigraphic stela found nearby (García Sanjuán et al. 2017) reflect a similar pattern, which must have been common along the Lower and Middle Guadalquivir valley during the LBA.

In the case of Setefilla, the necropolis was used for mortuary rituals during the LBA and the transition into the IA (the earliest urn-cremations in tumuli A and B), when the stela was most probably made and erected. At Setefilla, this corresponds with an occupation of dispersed huts made of perishable materials, metal smelting and long-distance exchange (Aubet 1983, pp. 77-86), a social context that sees the emergence of individuals or kin groups whose identity would be tightly linked to the stela (maybe representing a lineage's founding ancestor depicted as a warrior-hero?) and the tumuli in which they would be buried. In Mirasiviene, the data on the stela findspot is much more fragmentary and our knowledge 


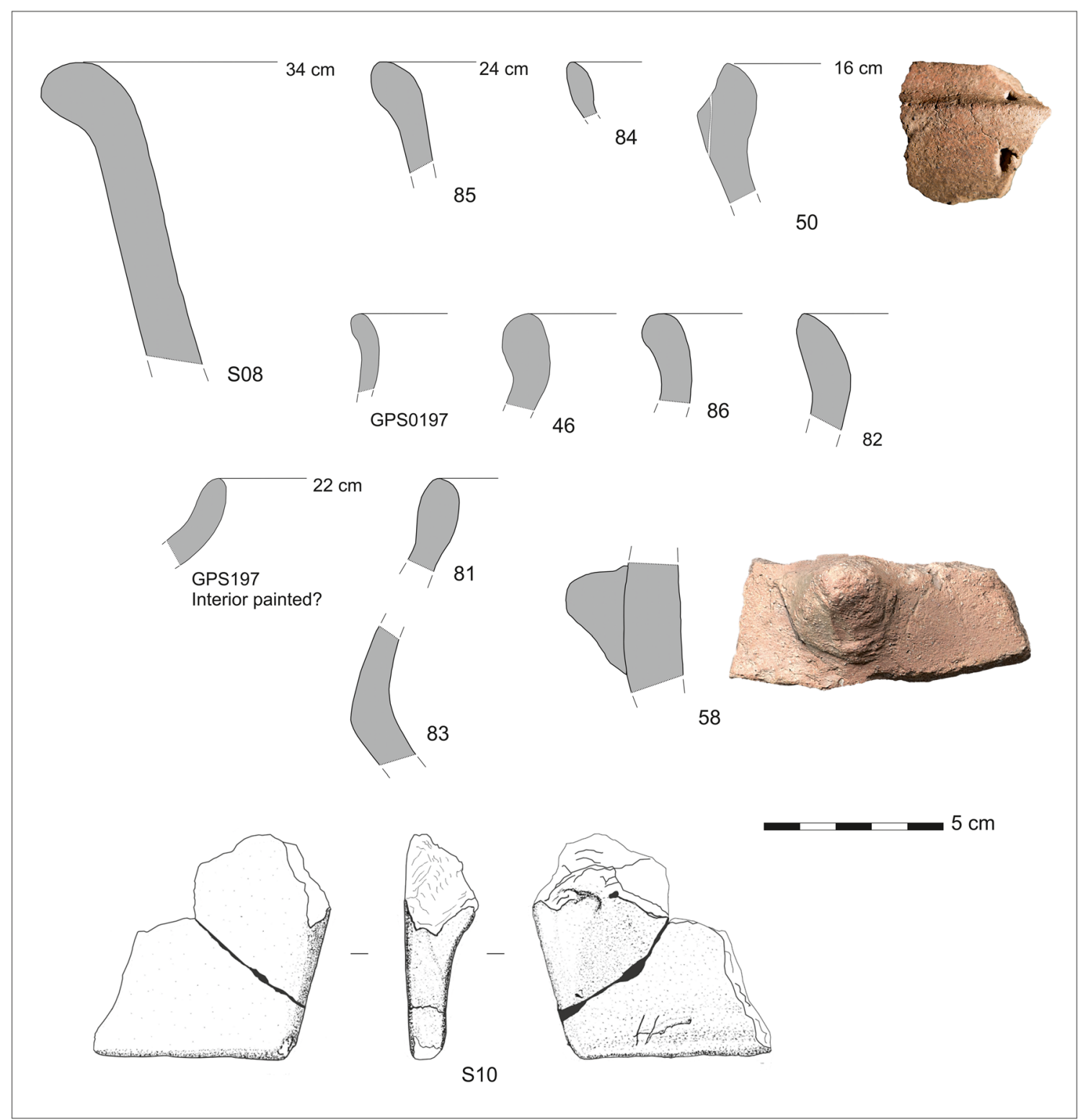

Fig. 25 Pottery sherds recorded in the settlement of Mirasiviene

of the settlement is shallower, but their spatial setting suggests a similar situation to that of Setefilla. Whilst we do not have evidence of funerary practices at Mirasiviene, the available data do suggest ritual activity linked to the monument, perhaps erected in memory of an emerging leader of the settlement.

That two stelae appear in such close proximity, marking the boundaries of two distinct settlements, does underline the identity dimension of these monuments. They would be visible to any passer-by approaching either of the two settlements and walking along the pathways at the foot of the sierras, but not from afar (when erected, they would be c. $1.50-1.60 \mathrm{~m}$ tall), and of course, they would be an ever-present reminder of the ancestors to the communities linked to them.

\section{Conclusions}

The results of the multidisciplinary, multiscale analysis of the Mirasiviene stela, its findspot and landscape context throw new light on the biographies, social contexts and landscape settings of warrior stelae. Such an approach has the potential to greatly expand our understanding of the roles of these monuments and the activities in which they engaged, questions that have puzzled researchers for more than a century.

Firstly, the detailed analysis of the slab and its engravings reveals that the stela was locally sourced and manufactured, most probably by non-specialists, who used technical solutions tailored to their specific needs, whilst reproducing some iconographic conventions that show 
Fig. 26 View of the Mirasiviene stela findspot from the top of its settlement

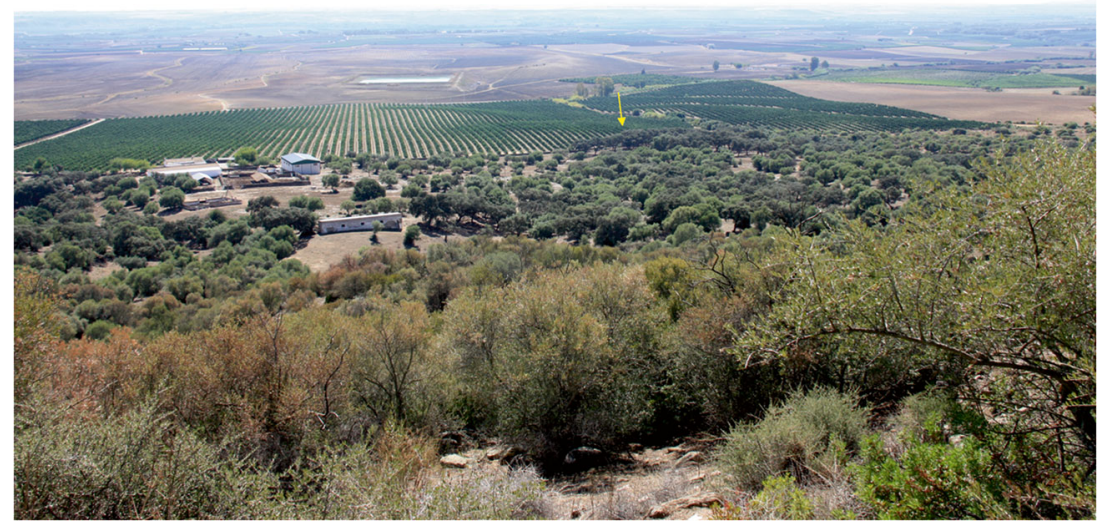

long-distance connections with other areas of the Lower and Middle Guadalquivir valley and the Middle Guadiana valley. The Mirasiviene stela also shares iconographic traits with the neighbouring Setefilla stela but, as the study of their respective chaîne opératoires of manufacture reveals, each one of these stelae was made using different techniques and carving sequences in order to shape the slabs and engrave the decoration. This suggests that stela-
Fig. 27 Visibility analysis ('observer points') of the Mirasiviene and Setefilla stelae findspots and associated settlements

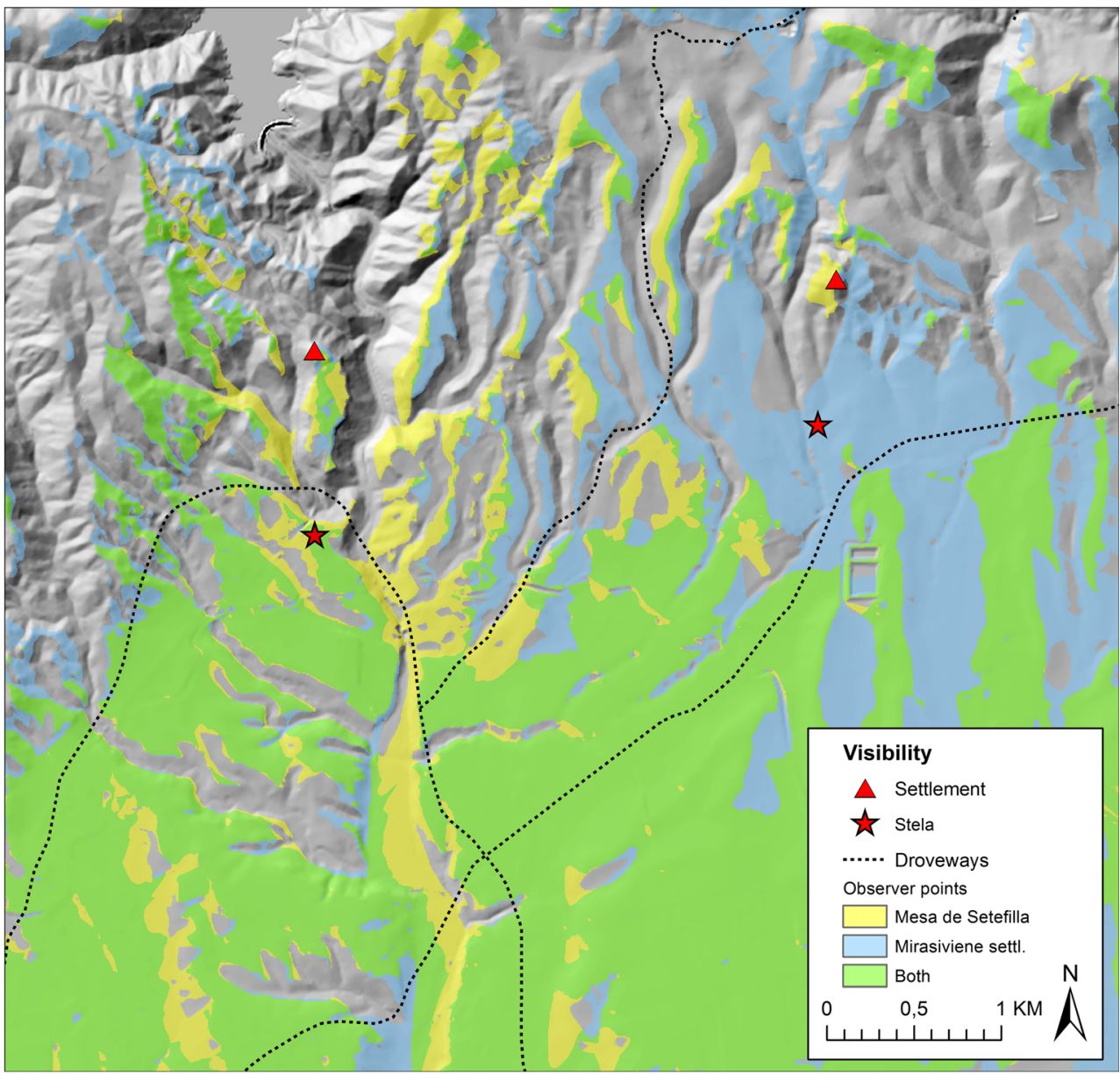


Fig. 28 Location of the Setefilla stela findspot, within the necropolis of Setefilla, and its nearby settlement, the Mesa de Setefilla

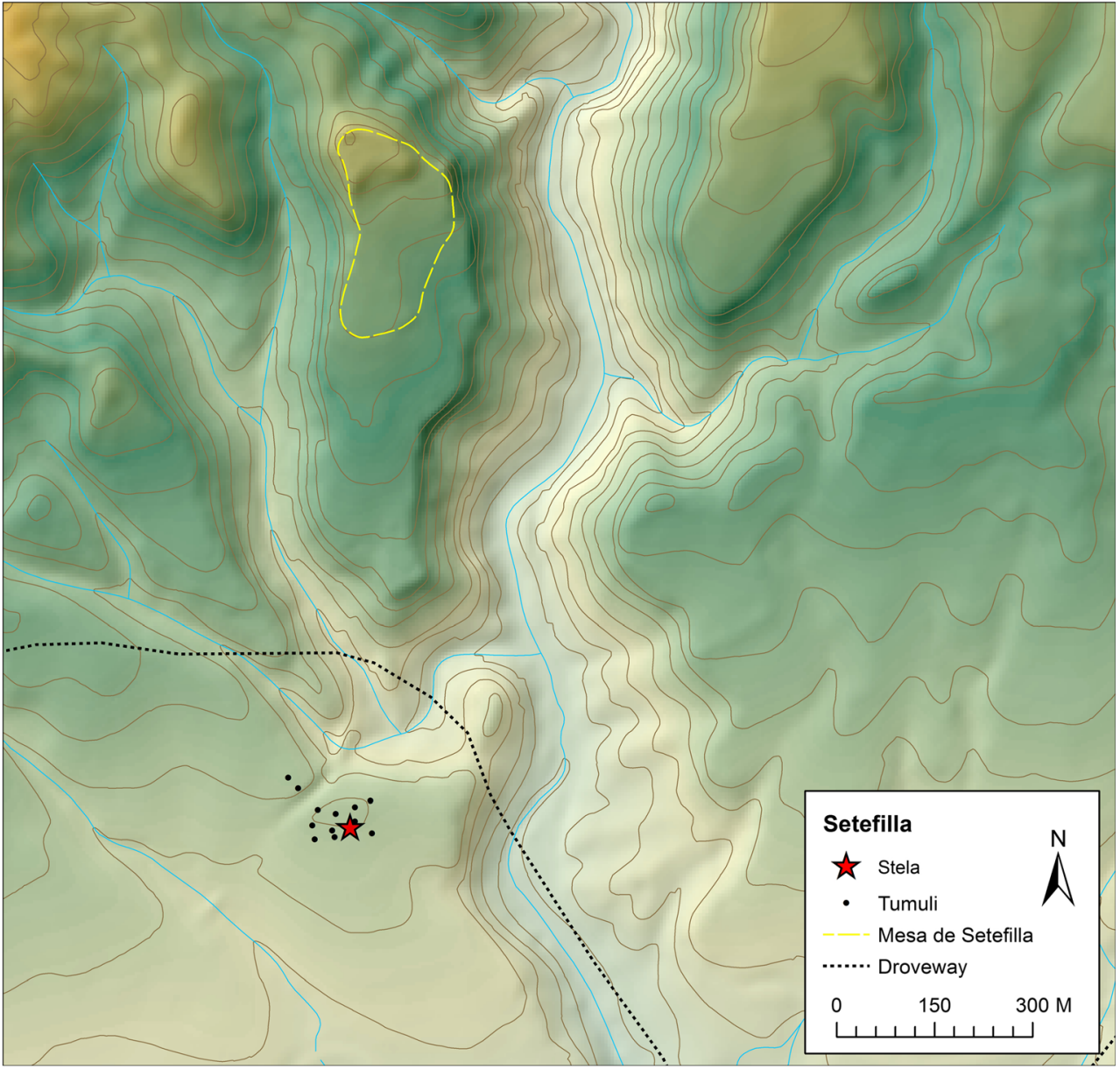

making was a local matter, each community engaging on it through its own tradition and know how, whilst at the same time using broadly shared ideas and concepts.

Fieldwalking at Mirasiviene revealed a remarkable concentration of archaeological material, particularly pottery, at the stela findspot. The material is diverse and some of it of recent date but, importantly, it includes lithic tools that could have been linked to the manufacture of the stela and a substantial sample of ceramic sherds from vessels whose shapes can be securely dated to the LBA/IA, when the stela was most probably made. This pottery shows technological commonalities with that found in the nearby Setefilla necropolis within contexts that have been radiocarbon dated to the LBA/EIA, indicating that they were made with similar recipes and that their clays were sourced in nearby locations.

The parallelism between Setefilla and Mirasiviene is stark. A warrior stela was also found in the Setefilla necropolis, reused as a cover of an EIA grave. The necropolis had a long-term persistent use but, as new radiocarbon determinations reveal, it was already being used as a funerary site (earliest urn-cremations of tumuli $\mathrm{A}$ and $\mathrm{B}$ ) when the manufacture of the warrior stela of Setefilla was taking place (at least according to the iconography). No evidence of funerary activities was documented at Mirasiviene, but the presence of bowls, plates and urns similar to those deposited at the Setefilla tombs during the LBA and the transition to the EIA suggests that during this time, vessels, possibly containing offerings, were placed at the stela findspot, suggesting a link between the stela and ritual activity.

Both the Setefilla and Mirasiviene settlements are located at almost the same distance (between 800 and $1000 \mathrm{~m}$ ) to the north of where their respective stelae were found. The Mirasiviene settlement seems to be smaller than that of Setefilla, whilst the date of its structures, which include an enclosure, is still uncertain, the archaeological material collected from its surface suggests a LBA occupation.

The analysis of the spatial setting of the Mirasiviene and Setefilla stelae findspots suggests that their locations seem to correspond to a pattern: both are located at the outskirts of matching settlements from which they can be seen, in places connected to water courses where ritual activities (funerary in the case of Setefilla) were carried out. From a spatial point of view, these are liminal places where stelae could have served not only as memorials but also as landmarks linked to specific settlements, the identity of their inhabitants or even certain 
individuals, family groups or 'houses', as it is suggested by the earliest urn-cremations deposited in the tumuli A and B in Setefilla.

At a macro-scale, the stela findspots of Mirasiviene and Setefilla are also linked to factors that have been traditionally considered key to the understanding of these monuments, such as their proximity to passage zones (Galán 1993) and valuable resources (Enríquez 2006), in this case, fertile arable soils in the Guadalquivir plain or metal ores from the Sierra Morena. But, as their most immediate contexts reveal, their spatial setting at a macro-scale is also closely linked to their roles within settlement complexes. This would be part of a broader trend, as it is suggested by the sparse data available for various stelae of the Tagus, Guadiana and Guadalquivir valleys (Díaz-Guardamino 2010, pp. 373-389). The three stelae of S. Martinho (Castelo Branco, Portugal, Tagus valley), for example, were found in the mid-slope of a large hill on top of which LBA occupation was documented, outside the stone enclosure (Díaz-Guardamino 2010, p. 371). The stela of Magacela (Badajoz, Spain, Guadiana valley) was located at the foothill of a prominent medieval castle where evidence of LBA occupation was recorded (Díaz-Guardamino 2010 , p. 379). Other stelae in the Guadiana valley were found within the catchment areas of LBA settlements, c. 3-5 km from them (Díaz-Guardamino 2010, pp. 378-381; Pavón et al. 2018). In the Guadalquivir valley, two interesting cases are the stelae of Montemolín (Sevilla) and Ategua (Córdoba), which appear at the foot of two prominent hills in which LBA settlement was recorded (DíazGuardamino 2010, p. 375). Finally, the stelae of Écija 2 and 4 (Seville) and Pocito Chico (Cádiz) were found within LBA settlements, the first two on the top of the site of the Atalaya de la Moranilla and the second reused in the fabric of a LBA hut (Díaz-Guardamino 2010, p. 375).

In short, when seen in their context, the Mirasiviene and Setefilla stelae appear as polyvalent monuments. They may well have served as memorials linked to individuals, remembered as ancestors, idealised warriors or heroes, possibly in connection to lineages, 'houses', kin groups or more extended communities. They also served as landmarks, set in liminal places, outside the limits of settlements, nearby pathways and waterways, on sacred grounds where burial and/or ritual activities were carried out. These were places whose significance persisted through time, most evidently in the case of Setefilla, but also plausible in the case of Mirasiviene, as the presence of some wheel-thrown painted pottery at the site and some of the carvings on the stela, possibly made on a later date, suggest.

Acknowledgements We would like to thank Mr. Eugenio and Mr. Pedro Antonio González Sanz and Mr. Pepe and Mr. Manuel, owners and managers of the farmstead of Mirasiviene, respectively, for the very helpful information they shared with us about the discovery of the stela, as well as for all their support to conduct this fieldwork project. We are also grateful to Mr. Juan José Toribio García and Mr. Juan Francisco López Muñoz for information about the whereabouts of the stela, as well as to Prof. Víctor Hurtado Pérez for inviting us to conduct this study.

Funding information The research was financed by the Spanish Ministry of Education (Programa Nacional de Movilidad de Recursos Humanos del Plan Nacional de I-D+i 2008-2011) (post-doctoral grant awarded to MDG) and the Polish National Science Centre (grant number DEC-2017/ 25/B/HS3/00635) (awarded to MK).

Open Access This article is distributed under the terms of the Creative Commons Attribution 4.0 International License (http:// creativecommons.org/licenses/by/4.0/), which permits unrestricted use, distribution, and reproduction in any medium, provided you give appropriate credit to the original author(s) and the source, provide a link to the Creative Commons license, and indicate if changes were made.

\section{References}

Almagro Basch M (1966) Las estelas decoradas del Suroeste Peninsular. Consejo Superior de Investigaciones Científicas, Madrid

Almagro-Gorbea M (1977) El Bronce Final y el período Orientalizante en Extremadura. Consejo Superior de Investigaciones Científicas. Instituto Español de Prehistoria, Madrid

Aubet ME (1975) La Necrópolis de Setefilla en Lora del Río, Sevilla, Barcelona

Aubet ME (1978) La Necrópolis de Setefilla en Lora del Río, Sevilla: (túmulo B). Departamento de Prehistoria y Arqueología, Barcelona

Aubet ME (1981) Nuevos hallazgos en la necrópolis tartésica de Setefilla. Mainake. Estudios de Arqueología Malagueña 2-3:87115

Aubet ME (1997) A propósito de una vieja estela. Saguntum (PLAV) 30: $163-172$

Aubet ME, Serna MR (1982) Una sepultura de la Edad del Bronce en la Mesa de Setefilla (Lora del Rio, Sevilla). Trab Prehist 39:225-251

Aubet ME, Serna MR, Escacena JL, Ruiz Delgado MM (1983) La Mesa de Setefilla. Lora del Río (Sevilla). Campaña de 1979, Excavaciones Arqueológicas en España. Ministerio de Cultura, Madrid

Barceló JA (1989) Arqueología, Lógica y Estadística: un análisis de las Estelas de la Edad del Bronce en la Península Ibérica. Universitat Autónoma de Barcelona, Barcelona

Bartkowiak M, Krueger M (2015) Wstepne rezultaty analizy petrograficz nej ceramikiz estanowiska Setefilla (Hiszpania). In: Krueger M (ed) Pozna ńskie studia nad najstar szymidziejam ilberii (Wielkopolskie Sparawozdania Archeologiczne 16). SNAP, Poznań, pp 37-45

Brandherm D, Krueger M (2017) First radiocarbon determinations from the Setefilla necropolis (Lora del Río) and the beginning of the Orientalizing period in western Andalusia. Trab Prehist 74(2):296318

Bonsor GE, Thouvenot R (1928) Nécropole Ibérique de Setefilla. Lora del Río (Sevilla). Fouilles de 1926-1927. Bourdeaux, Paris

Bronk Ramsey C (2017) Methods for summarizing radiocarbon datasets. Radiocarbon 59(6):1809-1833

Celestino Pérez S (2001) Estelas de guerrero y estelas diademadas. La precolonización y formación del mundo tartésico. Bellaterra, Barcelona

Cignoni P, Callieri M, Corsini M, Dellepiane M, Ganovelli, F, Ranzuglia G (2008). MeshLab: an open-source mesh processing tool In: Sixth Eurographics Italian Chapter Conference, pp. 129-36

Díaz-Guardamino M (2010) Las estelas decoradas en la Prehistoria de la Península Ibérica. Universidad Complutense de Madrid, Madrid 
Díaz-Guardamino M (2012) Estelas decoradas del Bronce Final en la Península Ibérica: datos para su articulación cronológica. In: Jiménez Ávila J (ed) Sidereum Ana II: El río Guadiana en el Bronce Final. Instituto de Arqueología de Mérida, Mérida, pp $389-415$

Díaz-Guardamino M (2015) Stones-in-movement: tracing the itineraries of menhirs, stelae and statue-menhirs in Iberian landscapes. In: Joyce RA, Gillespie SD (eds) Things in motion: object itineraries in anthropological practice. SAR Press, Santa Fe, pp 101-122

Díaz-Guardamino M (2019) Rock art as process: Iberian Late Bronze Age 'warrior' stelae in-the-making. In: Back Danielsson I-M, Jones AM (eds) Images in-the-making: art, process, archaeology (social archaeology and material worlds). Manchester University Press, Manchester (forthcoming)

Díaz-Guardamino M, García Sanjuán L, Wheatley DW (2015) RTI and the study of engraved rock art: a re-examination of the Iberian southwestern stelae of Setefilla and Almadén de la Plata 2 (Seville, Spain). DAACH 2:41-54. https://doi.org/10.1016/j.daach.2015. 07.002

Díaz-Guardamino M, García-Sanjuán L, Wheatley W, Lozano-Rodríguez JA, Rogerio-Candelera MA, Casado-Ariza M (2019). Late prehistoric stelae, persistent places and connected worlds: a multi-disciplinary review of the evidence at Almargen (Lands of Antequera, Spain)., Cambridge Archaeological Journal (forthcoming)

Díaz-Guardamino M, Wheatley D (2013) Rock art and digital technologies: the application of reflectance transformation imaging (RTI) and 3D laser scanning to the study of Late Bronze Age Iberian stelae, MENGA. Journal of Andalusian Prehistory 04:187-203

Domínguez de la Concha C, González Bornay JM, De Hoz Bravo J (2005) Catálogo de estelas decoradas del Museo Arqueológico Provincial de Badajoz (Siglos VIII-V a.C.). Consejería de Cultura, Junta de Extremadura, Badajoz

Enríquez Navascués JJ (2006) Arqueología Rural y Estelas del SO (desde la Tierra, para la Tierra y por la Tierra). Trabajos de Arqueología Navarra 14:151-175

Galán Domingo E (1993) Estelas, paisaje y territorio en el Bronce Final del Suroeste de la Península Ibérica. Universidad Complutense de Madrid, Madrid

García Sanjuán L (2011) The warrior stelae of the Iberian south-west: symbols of power in ancestral landscapes. In: Moore T, Armada Pita $\mathrm{L}$ (eds) Atlantic Europe in the first millennium BC: crossing the divide. Oxford University Press, Oxford, pp 534-557

García Sanjuán L, Díaz-Guardamino M (2015) The outstanding biographies of prehistoric monuments in Iron age, Roman, and medieval Spain. In: Díaz-Guardamino M, García Sanjuán L, Wheatley DW (eds) The lives of prehistoric monuments in Iron Age, Roman, and Medieval Europe. Oxford University Press, Oxford, pp 183-204

García-Sanjuán L, Díaz-Guardamino M, Wheatley DW, Vita JP, LozanoRodríguez JA, Rogerio-Candelera MA, Justo A, Barker D, Strutt K, Casado-Ariza M (2017) The epigraphic stela of Montoro (Córdoba, Spain): the earliest monumental script in Iberia? Antiquity 91(358): 916-932

García Sanjuán L, Wheatley DW, Fábrega Álvarez P, Hernández Arnero MJ, Polvorinos del Río A (2006) Las estelas de guerrero de Almadén de la Plata (Sevilla). Morfología, Tecnología y Contexto. Trab Prehist 63:135-152
Harrison RJ (2004) Symbols and warriors. Images of the European Bronze Age. Western Academics \& Specialist Press Ltd., Bristol

Hunt M (2003) Prehistoric mining and metallurgy in south west Iberian Peninsula, BAR International Series 1188. BAR Publishing, Oxford Jiménez Ávila J (2009) Arquitectura y Modalidad: La construcción del Poder en el mundo Post-orientalizante. Arch Esp Arqueol 82:69-95

Krueger M, Brandherm D (2019) Chemical characterization via pXRF of Early Iron Age pottery from SW Iberia. UISPP Journal 2:77-82

Martín de la Cruz JC (1987) El Llanete de los Moros (Montoro, Córdoba). Excavaciones Arqueológicas de España 151. Ministerio de Cultura, Madrid

Martín de la Cruz JC (1988) Mykenische keramic aus bronzezeitlichen siedlungsschichten von Montoro am Guadalquivir. Madrider Mitteilungen 29:77-92

Murillo JF (1994) La cultura tartésica en el Guadalquivir Medio. Museo Municipal de Lora del Río, Lora del Río

Murillo JF, Morena López JA, Ruiz Lara D (2005) Nuevas estelas de guerrero procedentes de las provincias de Córdoba y de Ciudad Real. Romula 4:7-46

Pavón Soldevila I, Duque Espino D M, Sanabria Murillo D y, Collado Giraldo H (2018). La estela de 'Cabeza del Buey V/El Palacio' en el poblamiento de la Edad del Bronce de la sierra de Tiros (Badajoz), SPAL 27(1), 31-60. doi: https://doi.org/10.12795/spal.2018i27.02

Pingel V (1974) Bemerkungen zu den ritzverzierten Stelen und zur beginnenden Eisenzeit im Südwesten der Iberischen Halbinsel. Hamburger Beiträge zur Archäologie 4:1-19

Reimer PJ, Bard E, Bayliss A, Beck JW, Blackwell PG, Bronk Ramsey C, Buck CE, Cheng H, Edwards RL, Friedrich M, Grootes PM, Guilderson TP, Haflidason H, Hajdas I, Hatté C, Heaton TJ, Hoffmann DL, Hogg AG, Hughen KA, Kaiser KF, Kromer B, Manning SW, Niu M, Reimer RW, Richards DA, Scott EM, Southon JR, Staff RA, Turney CS, Van der Plicht J (2013) IntCal13 and Marine13 radiocarbon age calibration curves 0-50, 000 years cal BP. Radiocarbon 55(4):1869-1887

Rogerio Candelera MA (2015) Digital image analysis based study, recording, and protection of painted rock art. Some Iberian experiences. DAACH 2:68-78. doi: https://doi.org/10.1016/j.daach. 2014.11.001

Roso de Luna M (1898) Lápida sepulcral de Solana de Cabañas, en el partido de Logrosán (Cáceres). Boletín de la Real Academia de la Historia 32-33:179-182

Ruiz Mata D (1995) Las cerámicas del Bronce Final. Un soporte tipológico para delimitar el tiempo y el espacio tartésico, Tartessos 25 años después. 1968-1993, Jerez de la Frontera, pp. 165-313

Torres M (1996) La cronología de los túmulos A y B de Setefilla. El origen del rito de la cremación en la cultura tartésica. Complutum $7: 147-162$

Turbón D (1981) Los restos humanos de Setefilla. Trab Prehist 38:225251

Vergne R, Pacanowski R, Barla P, Granier X, Schlick C (2010) Radiance scaling for versatile surface enhancement. In: Proceedings of the 2010 ACM SIGGRAPH symposium on interactive 3D graphics and games. ACM, pp 143-150

Publisher's note Springer Nature remains neutral with regard to jurisdictional claims in published maps and institutional affiliations. 